\title{
Thermoplastic Pultrusion: A Review
}

\author{
Kirill Minchenkov, Alexander Vedernikov, Alexander Safonov * (D) and Iskander Akhatov (D) \\ Skolkovo Institute of Science and Technology, Center for Design, Manufacturing and Materials, \\ 30/1 Bolshoi Boulevard, 121205 Moscow, Russia; kirill.minchenkov@skoltech.ru (K.M.); \\ aleksandr.vedernikov@skoltech.ru (A.V.); i.akhatov@skoltech.ru (I.A.) \\ * Correspondence: a.safonov@skoltech.ru
}

check for updates

Citation: Minchenkov, K.; Vedernikov, A.; Safonov, A.; Akhatov, I. Thermoplastic Pultrusion: A Review. Polymers 2021, 13, 180. https://doi.org/10.3390/polym 13020180

Received: 12 November 2020 Accepted: 30 December 2020 Published: 6 January 2021

Publisher's Note: MDPI stays neutral with regard to jurisdictional clai$\mathrm{ms}$ in published maps and institutional affiliations.

Copyright: $(\odot 2021$ by the authors. Licensee MDPI, Basel, Switzerland. This article is an open access article distributed under the terms and conditions of the Creative Commons Attribution (CC BY) license (https:// creativecommons.org/licenses/by/ $4.0 /)$.

\begin{abstract}
Pultrusion is one of the most efficient methods of producing polymer composite structures with a constant cross-section. Pultruded profiles are widely used in bridge construction, transportation industry, energy sector, and civil and architectural engineering. However, in spite of the many advantages thermoplastic composites have over the thermoset ones, the thermoplastic pultrusion market demonstrates significantly lower production volumes as compared to those of the thermoset one. Examining the thermoplastic pultrusion processes, raw materials, mechanical properties of thermoplastic composites, process simulation techniques, patents, and applications of thermoplastic pultrusion, this overview aims to analyze the existing gap between thermoset and thermoplastic pultrusions in order to promote the development of the latter one. Therefore, observing thermoplastic pultrusion from a new perspective, we intend to identify current shortcomings and issues, and to propose future research and application directions.
\end{abstract}

Keywords: thermoplastic pultrusion; thermoplastic composites; fiber-reinforced materials

\section{Introduction}

Today, polymer composite materials have found wide application in various industries [1,2]. This was made possible by extensive studies conducted over the last 70 years $[3,4]$. The popularity of composite materials results from their properties, such as high specific strength and stiffness [5-8]; improved durability [9,10]; high fatigue [11,12], chemical [13,14], and corrosion resistance [15-17]; and ease of transportation and assembly [18-20] of composite structures. Composite materials are produced by various processes, e.g., autoclave molding, resin transfer molding, compression molding, filament winding, and pultrusion [21,22]. Pultrusion is a process where a pack of reinforcement fibers impregnated by resin is pulled through a heated die block, where the polymerization process takes place [23]. This method allows fabrication of products having constant cross-section [24,25]. The advantages of pultrusion over other composite manufacturing processes are its high production rate of up to $5 \mathrm{~m} / \mathrm{min}[1]$, higher efficiency [26,27] and low costs [28,29] of production, and the ability to produce profiles of virtually indefinite length [30]. There are thermoplastic and thermoset matrix-based composites [31,32]. Thermosets are nonmelting polymers obtained during chemical reaction (polymerization) between a resin and a hardener, while thermoplastic composites can change their state and melt under heating. Fiber reinforcement is impregnated by hot melt thermoplastic polymer; then, after cooling, the part is ready for use. Compared to thermosetting composites, thermoplastic composites have higher impact toughness [33-36], are faster to produce [37,38], have higher service temperatures [39], can be joined by welding [40-43], have less environmental impact [44-46], and can be recycled [47-50]; their source materials have virtually unlimited shelf life [51-57]. Pultruded thermoplastic profiles are used in various structures and sectors, such as vehicles [58-63] and aircrafts construction [64-66], aerospace [67-69] and civil engineering [70-73], energy systems [74], restoration of deteriorated structures [75], marine applications [76-79], oil and gas industries [80], electromagnetic interference shielding elements [81,82], window profiles [83], pipes [84,85], rebars [86,87] and rods [88-91]. 
Today, the number of studies and publications in the field of thermoset pultrusion is an order of magnitude larger than the number of those in thermoplastic pultrusion, although advantages offered by thermoplastic composites provide enough reason for deeper study. From industrial point of view, it is worth noticing that, for instance, Fiberline Composites A/S, being one of the largest companies in the pultrusion manufacturing and the world's biggest web-shop of fiberglass profiles [92], has numerous types of pultruded structural profiles available for purchase with all of them being thermoset ones. Several questions arise in this connection. Why are there no thermoplastic profiles available for the customers to purchase, despite their numerous advantages? Why is there a well-developed market for thermosetting profiles and almost no market for thermoplastic ones?

Currently, there is no review on thermoplastic pultrusion. By analyzing the thermoplastic pultrusion process from different perspectives (technology, raw materials, properties, numerical modeling, applications, etc.) and recalling the main publications regarding thermoplastic pultrusion (scientific articles, patents), this article aims to understand why thermoplastic pultrusion failed to receive the attention and broad acceptance it deserves from the scientific and engineering community, as opposed to that of thermoset pultrusion. Exploring this issue, the authors intend to attract scientists' attention and stimulate further developments in thermoplastic pultrusion. Section 2 describes the process of thermoplastic pultrusion and components of pultrusion machines, provides the classification of thermoplastic pultrusion, analyzes basic parameters of pultrusion process, and reviews patents registered and future research possibilities. Section 3 discusses raw materials used in manufacturing of thermoplastic composites, mechanical properties of the pultruded profiles, and promising areas for the further investigations. Section 4 reviews the methods of process modeling and discusses of possible directions for scientific work. Section 5 analyzes the possible applications of thermoplastic profiles, patents registered, and future research and application possibilities.

\section{Thermoplastic Pultrusion and Process Parameters}

Luisier et al. were the first to propose the classification of thermoplastic pultrusion processes in two groups [93]. The first is nonreactive thermoplastic pultrusion where the process is based on the already polymerized materials, as opposed to the second onereactive thermoplastic pultrusion where thermoplastic is polymerized during chemical reaction between thermoplastic resin and catalyst/activator, with simultaneous impregnation of fiber reinforcement (Figure 1) [93].

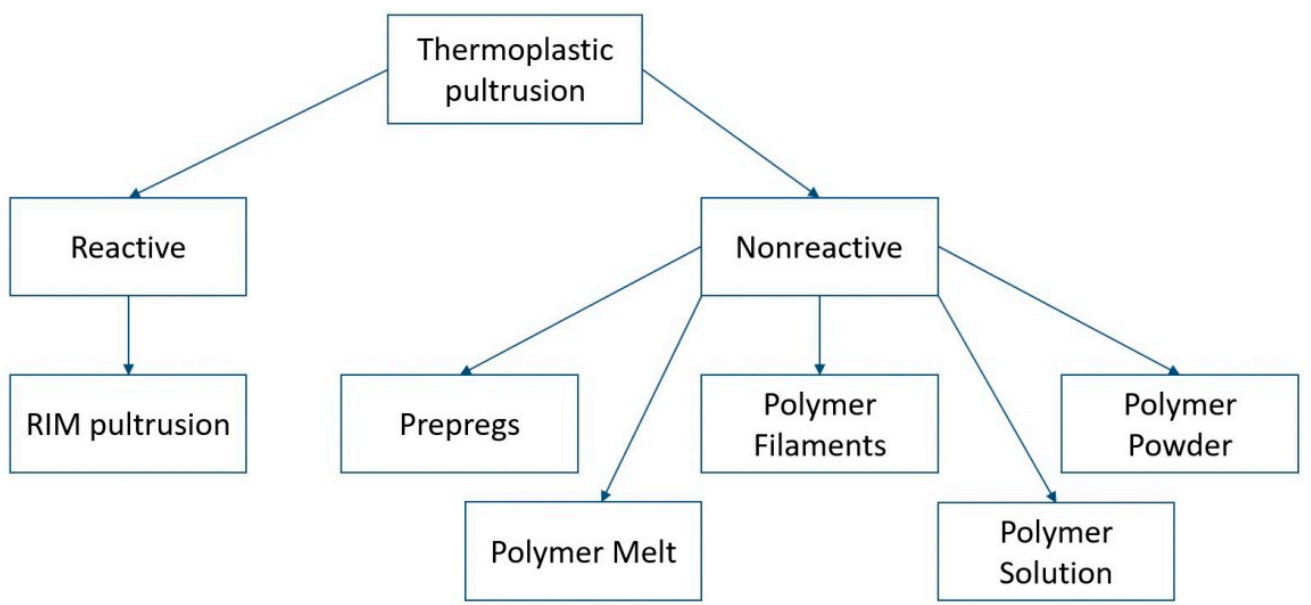

Figure 1. Thermoplastic pultrusion types.

A nonreactive pultrusion machine for thermoplastic composites consists of towpregs bobbins, guiding system, preheating chamber (preheater), heated forming die, cooling die, puller, and a cutting saw (Figure 2) [30]. Pretreated fibers, blended intimately with 
thermoplastics at the filament level at certain ratio, are fed into the guiding system in order to prevent their entanglement and to distribute fibers over the whole section of the profile. Collimated fibers are then fed into a preheater and heated to a temperature above the melting point of the thermoplastic in order to reduce the time the reinforcement stays in the heated die block and to ensure uniform impregnation of reinforcement. Various types of heating systems can be used in the process, such as convective [94], infrared [95-97], contact [98], and microwave [99]. In practice, contact heating systems demonstrate higher efficiency, as compared to convective ones [94]. After exiting the preheating chamber, uniformly heated material enters the heated die block where the melting of thermoplastic takes place and the profile assumes its final shape. In order to accelerate the consolidation of the polymer, the formed profile is fed into the cooling die where it is cooled to the near-ambient temperature. At the last stage the profile is cut to the required lengths with a flying saw [100].

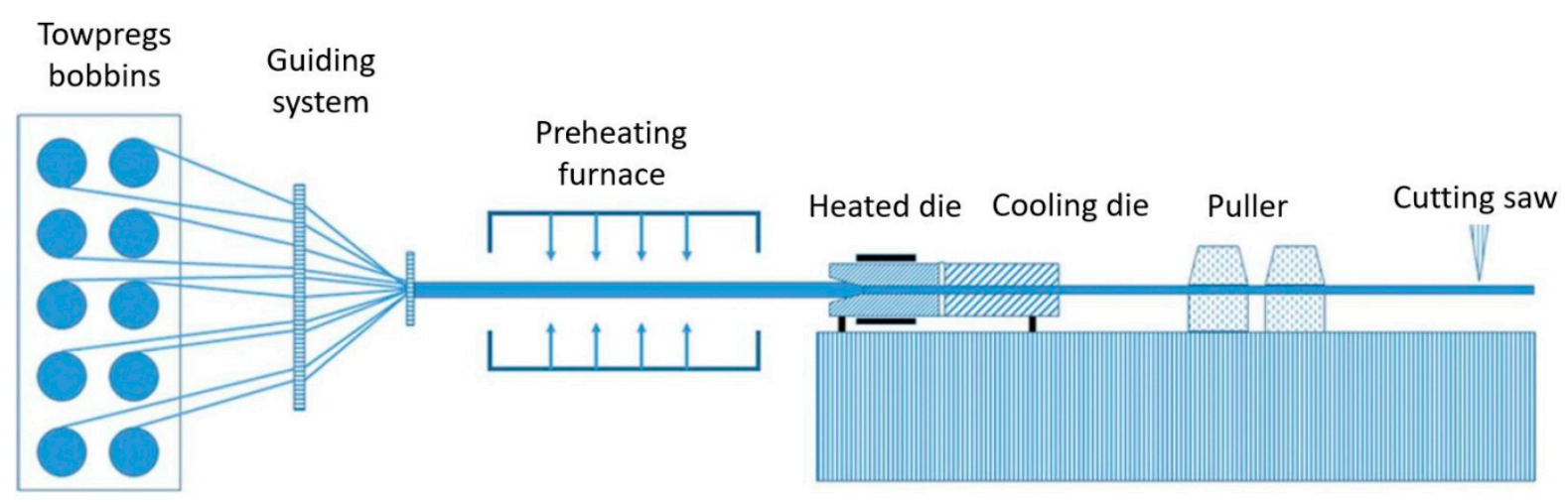

Figure 2. Schematic diagram of the nonreactive thermoplastic pultrusion line.

Nonreactive pultrusion machines can also incorporate braiding appliances [101,102]. Bechtold et al. [94] have successfully combined pultrusion and braiding, producing the profile with additional external reinforcement. The Daimler AG company has investigated and patented the braided pultrusion machine allowing fabrication of hollow profiles [103-107]. Memon and Nakai [108] used the combination of pultrusion and braiding to fabricate pipes reinforced with jute fiber. They tested various pulling speeds, temperatures, and pulling forces, and also investigated the influence of braiding parameters such as the braiding angle, the gap between braiding yarns, and the filling ratio.

From the industrial point of view, it is worth noting the knowledge that was developed in the leading countries with patents on thermoplastic pultrusion: USA, China, Germany, and France. Engineers developed various techniques to control the tension of the filaments [109,110], the pressure in the die [111,112], and the size of the die cavity $[113,114]$. Different techniques of fiber impregnation [115-120] and material feeding, such as sheet feeding of fibers and thermoplastics [121] and individual fiber feeding [122,123], were developed. Pultrusion is normally used to create profiles of constant cross-section; however, engineers from Boeing and the Phillips Petroleum Company modified the mechanics of the process, making it possible to produce profiles of variable cross-section, either by using multiple dies [124,125] or by modifying the die system [126-130].

The combination of pultrusion and reaction injection molding (RIM) resulted in development of the RIM pultrusion (reactive pultrusion) process similar to the combination of thermoset pultrusion and injection molding [131-136], patented by Industrial Technology Research Institute in 1993 [137]. The main difference between the reactive and nonreactive pultrusion processes is the design of the heated die block. In the reactive pultrusion process, preheated unimpregnated fiber is fed into the heated die block where fiber impregnation and polymerization of matrix take place (in situ polymerization), and the polymerized matrix has properties of thermoplastic melt [40]. The following polymers are typically used in the RIM pultrusion: polycarbonates (PC), polyesters (PE), polyurethanes (PU), 
polymethylmethacrylates (PMMA), and polyamides (PA) (in particular, PA-6 synthesized from $\varepsilon$-caprolactam ( $\varepsilon$-CL) monomer) [138]. Figure 3 shows a schematic illustration of the RIM pultrusion die block [139].

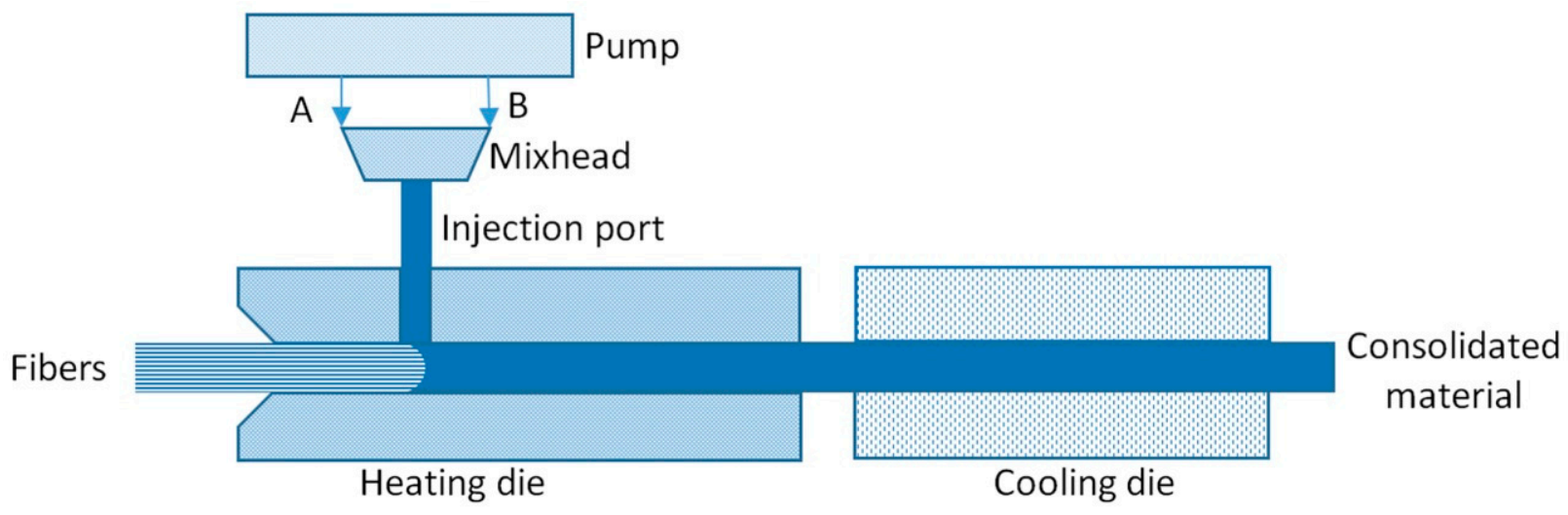

Figure 3. Scheme of the reaction injection molding (RIM) pultrusion die block.

The important advantage of reactive pultrusion lies in the low viscosity of thermoplastic resin solution as opposed to thermoplastic polymers, which improves and accelerates impregnation and, in turn, increases production rate. The important factor is the rate of polymerization, as it can take 1 to $60 \mathrm{~min}$ for polymerization to complete, depending on the temperature and monomer-to-activator ratio [140-142].

Further in the chapter we will discuss the parameters of the nonreactive thermoplastic pultrusion process, such as preheater temperature, temperature and geometry of the heated die, pressure inside the heated die, cooling die temperature, pulling speed, and pulling force, and their influence on the production process. We will not limit the discussion to the description of the process, but will also include a brief overview of articles investigating a particular manufacturing parameter from a scientific point of view, and, finally, note promising areas for future research.

\subsection{Preheater Temperature}

The aim of a preheating system analysis is to find the optimum temperature that would allow maximum increase in production rate without compromising the performance of the profiles produced. Increase in pulling speed reduces the time a material stays in the preheating chamber and, thus, requires the use of more efficient heating techniques. In 1997, Carlsson and Astrom [95] suggested that a preheater should meet the following requirements: the heating should be noncontact (to prevent melting of thermoplastic), continuous (to prevent overheating and degradation of the material), and uniform (to prevent temperature differences in a material).

However, as was shown in practice, the use of a contact preheater allows engineers to speed up the process, increase heating efficiency, and improve the shear strength of the material [94]. The optimum preheater temperature is assumed to be close to the melting temperature of a thermoplastic, in spite of the fact that high preheating temperature reduces the viscosity and drag while reducing the probability of fiber breakage [143]. On the other hand, preheating temperature that exceeds the thermoplastic melting temperature may cause the partial loss of material and increased void content, especially when using contact preheaters. In addition, high preheat temperatures result in the higher surface roughness of a product [95].

Kerbiriou and Friedrich [144] experimentally studied basic manufacturing parameters, namely temperature conditions on the preheater, heated die and cooling die, pressure in the heated die, and pulling speed, and their influence on density and mechanical properties. At the same time, Bechtold et al. [145] studied the effects of preheating, heated die temperature, and pulling speed on the mechanical characteristics by using glass fiber- 
polyamide 6 (Nylon 6) microbraided yarn. The influence of preheating temperature on the properties of produced profiles was determined by Evstatiev et al. [146].

\subsection{Temperature and Geometry of the Heated Die}

The main component of the nonreactive pultrusion machine is the heated die block. The purpose of the die block is to melt the matrix, to impregnate fibers, and to impart a shape to the composite. To control the process of pultrusion, manufacturers equip the heated die block with thermocouples, pressure gauges, and electrical heaters [147]. On the one hand, the increase in temperature lowers the viscosity of the matrix, and increases pressure due to the thermal expansion, thus improving the impregnation of fibers [98]. As shown experimentally by Carlsson and Astrom [95], the increase in temperature results in better mechanical performance of the glass fiber and polypropylene (GF/PP)-based composite. On the other hand, the maximum temperature is limited by the temperature of thermal degradation of polymers [148], which, if exceeded, can result in polymer burn-out and rejected products. High pressure and temperature may cause the fracture of reinforcing fibers. Also, low viscosity in combination with low pulling speed and high pressure may force the matrix to move backward and accumulate at the entrance of the heated die [98]. Figure 4 shows the typical distribution of temperatures during the pultrusion process [149].

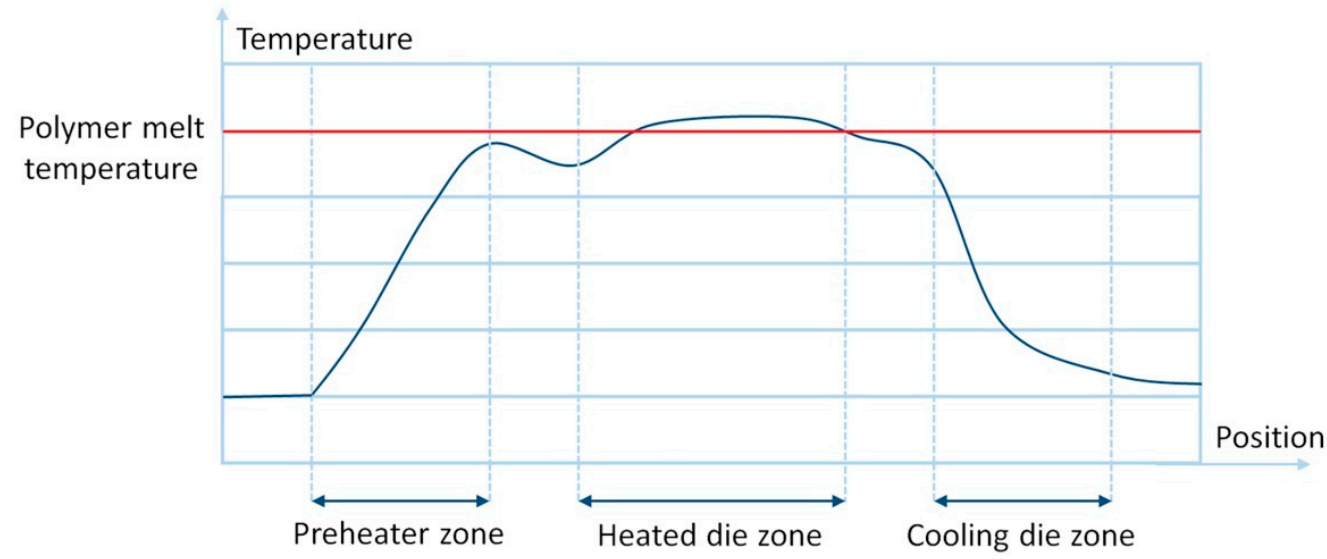

Figure 4. Typical distribution of temperatures inside the pultrusion machine.

Experimental trials with different die geometries were carried out by Michaeli and Jurss [147]. Evstatiev et al. explored the influence of heated die temperature on the properties of pultruded profiles, using scanning electron microscopy, wide-angle X-ray scattering, and mechanical testing [146]. In the study with jute fiber composites [108], Memon et al. observed an increase in flexural strength at a certain temperature; however, further increase in temperature resulted in a reduction thereof. Schafer and Gries [150] proposed the unconventional heating method for braided pultrusion process. Simultaneously, Oswald et al. [151] analyzed the influence of temperature regime on the void content of thermoplastic pultruded profiles based on natural fibers, and investigated the influence of heating conditions on the void content. Optimized parameters of the pultrusion process (temperature conditions in particular) were investigated by Wongsriraksa and Nakai [152]. In [153], the effects of heating conditions on the mechanical performance of carbon fiber reinforced polymer (CFRP) composites were experimentally evaluated. Chen et al. [154] analyzed correlation between die temperature and properties (crystallinity, melting point, mechanical properties) of the manufactured profiles. At the same time, Lapointe and Laberge Lebel [149] investigated the use of a multi-die system for the better impregnation of thermoplastic pultruded rods.

Another important parameter affecting the impregnation of fibers is the geometry of the heated die block [149], the inner part of which has a tapered section linearly narrowing to the die exit (Figure 5) $[155,156]$. Near the exit of the die block, the cross-section becomes 
constant and assumes the geometry corresponding to the desired shape of a composite [157]. The tapered section of the die block is described by the angle of taper that affects the pressure and backward motion of the thermoplastic melt. In order to minimize friction between a composite and internal surfaces of the die block, and to reduce the pulling force, the internal surfaces of the die block are chromium plated [158]. In addition to the tapered die block designs where the reinforcement pack is shaped and impregnated by way of pressure exerted upon a material by internal surfaces of the die block, there is also a die block design where the thermoplastic melt is forced into fibers by special pins [97].

Taper angle
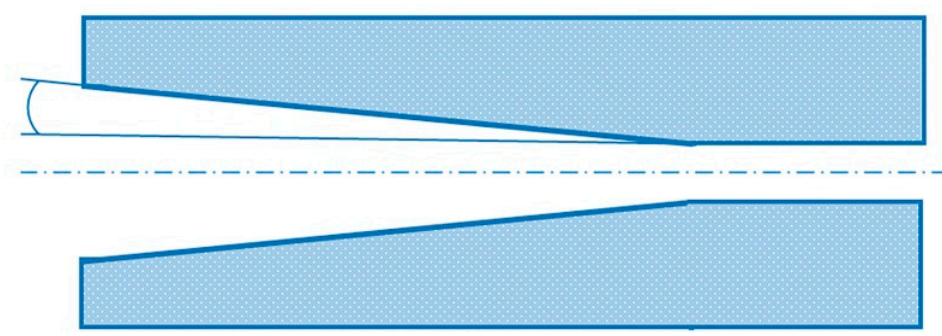

Figure 5. Angle of taper of the heated die.

\subsection{Heated Die Pressure}

The process of fiber impregnation depends on the pressure. Pressure, in turn, depends on the viscosity of a polymer, pulling speed, and the angle of taper [157]. Pressure in a die block originates from thermal expansion of a polymer inside a tapered die block [147]. It is very difficult to evaluate the influence of pressure on the quality of a composite experimentally, as high pressure values can only be achieved at high pulling speed that adversely affects the quality of material because of resulting high void content [147]. Fanucci et al. [159] manufactured special sensors and studied their application for pressure registration during thermoplastic pultrusion.

\subsection{Temperature of a Cooling Die}

The profile exiting the die block can lose its shape under external forces due to plasticity of the polymer at high temperatures. To prevent the loss of shape, it is necessary to cool the profile below the glass transition temperature [147]. As the profile already has the desired shape at the cooling stage, the cooling die has a constant cross-section. In order to achieve a sharp temperature gradient, the distance between the heated and cooling dies is rather small [157]. The experiments by Carlsson et al. [95] and by Kerbiriou et al. [144] show that cooling temperature influences the surface roughness of a product, and its flexural and shear strength.

Astrom et al. [143] experimentally investigated the influence of process parameters in general, and of the cooling die in particular, on the degree of crystallinity, and, therefore, on the mechanical properties of thermoplastic composites. More recently, Michaeli and Blaurock [160] discussed the relationship between cooling zone parameters and surface quality of produced profiles. Ghaedsharaf et al. [161] studied the effects of cooling die temperature and pulling speed on the resin impregnation, void content, and quality of the final surface.

\subsection{Pulling Speed}

The most important pultrusion parameter affecting all other parameters is the pulling speed. The pulling speed determines the time the reinforcement and a polymer stay within the preheater and inside a die block. Impregnation, pressure within the heated die block, pulling force, heating uniformity, and viscosity of thermoplastic melt-all depend on the pulling speed [98]. It was experimentally established that reduction in flexural strength is associated with increase in a pulling speed [162,163]. In addition, the increase in a pulling speed can adversely affect the shear strength and interlaminar shear strength [162]. 
Carlsson and Astrom [95] observed formation of defects at specimen surfaces with the increase in pulling speed. They attributed it to matrix sticking to the internal surfaces of the heated die block due to high pulling speed and high cooling temperature. Wiedmer and Manolesos also observed the shift from glossy to rough surfaces [98].

The relationships between pulling speed and compressive, flexural, and interlaminar shear strength of thermoplastic pultruded composites were experimentally analyzed by Astroem et al. [164]. Cho et al. [139] investigated the influence of pulling speed, heating temperature, and the reinforcement volume fraction on the temperature evolution of the resin, its conversion, and physical and mechanical characteristics. At the same time, aiming to achieve higher pulling speeds, Squires et al. conducted an experimental study by varying heating and cooling temperatures, as well as pressure profiles [165]. Azari [166] investigated the influence of pulling speed on the wet-out and mechanical properties of pultruded strands. Seeking to optimize pulling speed, Ozturk et al. explored the sensitivity of the process to changes in the pulling speed by changing the manufacturing parameters of the pultrusion line [167]. Subsequently, the effects of pulling speed on the microstructural and mechanical characteristics of pultruded profiles were investigated by Evstatiev et al. [146]. Nunes et al. [168] analyzed the influence of pulling speed and heating temperature on the mechanical and physical properties of pultruded profiles manufactured of towpregs. The effect of pulling speed on the mechanical performance of CFRP composites was evaluated by Wongsriraksa and Nakai [153]. Pulling speed optimization in the case of glass-fiber-reinforced polyamide-6 (PA-6) composite manufactured by thermoplastic reaction injection pultrusion technique is discussed in [154]. Simultaneously, Lapointe and Laberge Lebel investigated effects of pulling speed on the void content and quality of impregnation [149].

\subsection{Pulling Force}

Pulling force can change depending on the pulling speed, section geometry, taper angle, and viscosity of a polymer. The critical value of pulling speed should be tightly controlled in order to prevent production interruptions and to maintain the integrity of a profile [169]. As shown by Carlsson and Astrom [95], the pulling speed is the main factor affecting the pulling force. Astrom [155] succeeded in establishing the relation between the taper angle and pulling force. At angles exceeding $5^{\circ}$, the pulling force is relatively low; the drastic increase in pulling force is observed with the decrease in the angle of taper. In addition, the increase in the perimeter of a profile cross-section also results in the increased pulling force. The correlation between pulling force and pulling speed was experimentally investigated by Nakai and Morino [170].

\subsection{Future Trends}

Analysis of the thermoplastic pultrusion process and its parameters, as well as consideration of thermosetting pultrusion scientific and industrial state-of-the-art, demonstrate that deeper research is needed to better understand the peculiarities of the thermoplastic pultrusion process. The deeper knowledge of the thermoplastic pultrusion process will stimulate the interest in this manufacturing technique from the scientific and engineering community. This subchapter briefly discusses promising directions for future investigations in this field. All the topics listed below require careful research, since there are currently few publications available on the mentioned subject, or research has not been conducted at all.

Although some relationships between process parameters and mechanical characteristics of the thermoplastic pultruded products have been established, extensive experimental research is needed to understand the direct influence of these parameters on each of the following mechanical properties at different loading conditions and strain rates: tension, compression, flexure, buckling, shear, creep, and fatigue. Degree of crystallinity, melting, and consolidation evolution during polymerization depends on the temperatures used; thus, a deeper understanding of this interconnection is necessary in order to improve 
process outcomes. The influence of the die geometry defining the thickness of the manufactured profiles and, thus, determining mechanical properties and shape distortions of the final product, also requires detailed research. Moreover, severity of process-induced shape distortions both in thermoset $[12,23,171]$ and in thermoplastic pultrusion depends on the temperature and, therefore, is another potential field of investigation. The relationship between process parameters and formation of voids, cracks, and delaminations also require in-depth research. A successful application of thermoplastic pultruded structures in harsh and severe environments will require better understanding of the influence of process parameters on the service life of the produced profiles.

Finally, in order to avoid expensive trial-error experiments when studying the influence of process parameters of the thermoplastic pultrusion, we need better optimization and numerical simulation algorithms. Moreover, the existing models require refinement to improve control over process parameters and to obtain better outcomes of the thermoplastic pultrusion process.

The studies discussed above mostly deal with profiles of simple cross-sections (rods, flat profiles). Currently, there is a lack of studies describing the thermoplastic pultrusion of complex shape profiles, such as pipes, channels, I-beams, decks, etc., commonly used in the construction industry. Despite the large number of publications on pultrusion with unidirectional reinforcement, there are no studies on thermoplastic pultrusion with various reinforcement types, and on application of fabrics, mats, and veils. Moreover, there are no studies on the stability of the thermoplastic pultrusion process; i.e., how many profiles (particularly of complex shape) of steady, acceptable quality can be produced within a single manufacturing cycle. Furthermore, successful scaling, development, and industrial application of thermoplastic pultrusion will require more studies on manufacturing process controls and elimination of defects.

\section{Raw Materials and Properties of Obtained Composites}

Final properties of a material depend both on the quality of manufacturing and on the quality of raw materials. The main problem in thermoplastic composite manufacturing is the need to ensure good impregnation of reinforcing fibers with matrix, as the viscosity of thermoplastic polymers is significantly higher than that of the thermosetting ones, e.g., the average viscosity of thermosetting polymers is $0.03-1 \mathrm{~Pa} \cdot \mathrm{s}$ [142], as opposed to 500-5000 Pa.s [172] in case of thermoplastic ones. One way to simplify the process of nonreactive thermoplastic pultrusion is the use of prepregs where reinforcing fibers are in the close contact with matrix uniformly distributed over the whole length of a prepreg. When the prepreg enters the die block, thermoplastic polymer contained in the prepreg will melt and impregnate the fibers under pressure. Tables 1 and 2 show properties of some polymers and fibers used in the thermoplastic pultrusion.

Longmuir and Wilcox proposed a novel technique allowing a variable number of fiber strands to be used during the manufacturing process [173]. Thomasset et al. performed a rheological study on the polypropylene and long-glass-fiber composites manufactured by pultrusion [174]. Simultaneously, Broyles et al. [175-177] studied the influence of fiber sizing agents on the mechanical properties and moisture absorption. Next, Roy et al. $[178,179]$ succeeded in improving compression behavior of pultruded composites by modifying material composition and parameters of the thermoplastic pultrusion process. Subsequently, Fink and Ganster [180] conducted an experimental study of the influence of synthetic fibers and of the choice of matrix on mechanical properties of composites. A novel tool intended for the manufacturing of thermoplastic pultruded profiles was proposed by Novo et al. [181]. Tao et al. [182] analyzed mechanical performance, thermal stability, and morphology of composites based on long- and short-glass-fiber reinforcements. The influence of fiber content on mechanical and tribological properties, morphology, and thermal stability of pultruded polyoxymethylene (POM)-basalt fiber composites was studied by Wang et al. [183]. Kahl et al. [184] used different types of reinforcement (cellulose and glass fibers) and matrix material (polypropylene and polyamide) to evaluate the influence of raw 
materials on the mechanical performance of manufactured specimens. Shayan Asenjan et al. [185] conducted the experimental study to understand a correlation between the length of fibers and high-velocity impact performance. Chen et al. [154] investigated the influence of volume fraction of reinforcement on the density, heat distortion temperature, void occurrence, and mechanical characteristics of the glass fiber-polyamide-6 (PA-6) composites produced by RIM pultrusion. Recently, the relationship between impregnation and mechanical properties was studied by Saito et al. [186]. At the same time, seeking for a reduction in carbon footprint, Asensio et al. [187] studied the possibility to use recycled material for the pultrusion of thermoplastic composites.

Table 1. Polymers used as a matrix in thermoplastic pultrusion.

\begin{tabular}{|c|c|c|c|c|c|c|c|c|}
\hline Material & $\begin{array}{l}\text { Melting } \\
\text { Point, }{ }^{\circ} \mathrm{C}\end{array}$ & $\begin{array}{l}\text { Glass Transition } \\
\text { Temperature, }{ }^{\circ} \mathrm{C}\end{array}$ & $\begin{array}{l}\text { Density, } \\
\mathrm{g} / \mathrm{cm}^{3}\end{array}$ & $\begin{array}{c}\text { Elastic } \\
\text { Modulus, } \\
\text { GPa }\end{array}$ & $\begin{array}{l}\text { Tensile } \\
\text { Strength, } \\
\mathrm{MPa}\end{array}$ & $\begin{array}{c}\text { Flexural } \\
\text { Modulus, } \\
\text { GPa }\end{array}$ & $\begin{array}{c}\text { Flexural } \\
\text { Strength, } \\
\mathrm{MPa}\end{array}$ & Reference \\
\hline PBT & $230-223$ & $31-60$ & $1.21-1.38$ & $1.8-2.5$ & $40-55$ & $1.9-2.8$ & 76 & [188-191] \\
\hline PA 6 & 220 & $49-75$ & $1.10-1.12$ & 2.8 & $48-80$ & $1.9-3.2$ & $69-117$ & {$[189,191,192]$} \\
\hline PA 66 & 268 & $60-70$ & $1.06-1.12$ & $2.8-3.9$ & $30-85$ & $1.2-3.7$ & 86 & {$[189,191,193,194]$} \\
\hline PA 12 & $174-185$ & 55 & $1.01-1.03$ & $0.5-1.9$ & $45-70$ & $0.36-1.2$ & - & [191] \\
\hline PP & $160-175$ & $-15--8$ & $0.89-0.92$ & $1.0-2.0$ & $28-41$ & $0.8-1.7$ & $45-55$ & {$[169,188,189,191-193,195]$} \\
\hline PEEK & $334-345$ & $143-158$ & $1.29-1.34$ & $3.1-8.3$ & $90-115$ & $2.8-3.9$ & 110 & {$[149,169,188,191,192,196]$} \\
\hline PEKK & 360 & $154-171$ & $1.27-1.31$ & 4.0 & 110 & - & - & {$[188,189,191]$} \\
\hline PET & $243-250$ & $60-88$ & $1.30-1.38$ & $2.5-4.0$ & $50-70$ & 2.8 & 110 & {$[188,189,191,193]$} \\
\hline PEI & $216-220$ & $209-249$ & $1.26-1.70$ & $2.7-6.4$ & 100-105 & $2.9-3.3$ & 151 & {$[188,189,191,196]$} \\
\hline PES & $220-238$ & $220-246$ & $1.36-1.58$ & $2.4-8.6$ & $83-126$ & & & {$[188,191]$} \\
\hline PMAA & $105-160$ & $82-105$ & $1.17-1.26$ & $2.8-3.4$ & 62 & 3.2 & 97 & {$[191,193]$} \\
\hline PPS & $280-290$ & $74-92$ & $1.35-1.43$ & $3.4-4.3$ & $66-93$ & $3.4-4.1$ & $96-151$ & {$[188,189,191,192,196,197]$} \\
\hline PLA & $150-162$ & $55-75$ & $1.18-1.26$ & $0.5-3.5$ & $21-170$ & $1.8-2.8$ & - & {$[189,191,195]$} \\
\hline HDPE & $130-137$ & $-133--118$ & $0.95-0.97$ & $0.7-1.4$ & $20-40$ & 1.2 & - & {$[189,191,195,198]$} \\
\hline LDPE & $105-125$ & $-133--103$ & $0.92-0.93$ & $0.1-0.4$ & $5-17$ & - & - & {$[189,191]$} \\
\hline PC & $255-267$ & $-158--134$ & $1.18-1.22$ & 2.4 & $55-75$ & $2.1-2.4$ & $80-93$ & [189-193] \\
\hline PE & 104-113 & $-133--59$ & 0.92 & 0.2 & $10-18$ & - & - & {$[188,191]$} \\
\hline PU & $220-230$ & $-60--19$ & $1.15-1.25$ & $0.1-0.7$ & $5-28$ & - & - & [188] \\
\hline
\end{tabular}

Table 2. Fibers used as reinforcement in thermoplastic pultrusion.

\begin{tabular}{cccccc}
\hline Material & $\begin{array}{c}\text { Density, } \\
\text { g/cm }\end{array}$ & $\begin{array}{c}\text { Tensile } \\
\text { Modulus, } \\
\text { GPa }\end{array}$ & $\begin{array}{c}\text { Tensile } \\
\text { Strength, } \\
\text { GPa }\end{array}$ & $\begin{array}{c}\text { Poisson's } \\
\text { Ratio }\end{array}$ & Reference \\
\hline E-Glass & $2.5-2.54$ & $70-73$ & $1.5-2.3$ & $0.20-0.30$ & {$[1,188,189,199]$} \\
S-Glass & 2.46 & 90 & 4.5 & $0.21-0.23$ & {$[1,188]$} \\
Carbon & $1.94-2.15$ & $585-725$ & $2.2-3.8$ & $0.25-0.30$ & {$[1,188]$} \\
Flax fibers & 1.5 & 50 & $0.5-0.9$ & - & {$[1,189]$} \\
Jute fibers & 1.3 & 26.5 & $0.4-0.7$ & - & {$[200]$} \\
Hemp fibers & 1.45 & 64 & 0.69 & - & {$[189]$} \\
Graphite & 1.90 & 3.3 & - & 0.28 & {$[197]$} \\
Aramid & 1.45 & 125 & $2.8-3.5$ & 0.35 & {$[188,199]$} \\
\hline
\end{tabular}

Various additives (fillers), with the most popular being nanotubes, can improve the performance of composites. Nanotubes improve interlaminar shear strength, interfacial shear strength, and delamination resistance of a composite [201,202]. Addition of Ni powders increases the flexural modulus; the optimal ratio of matrix, filler, and Ni powder improves the mechanical performance of composites [81]. Various fiber coatings make it possible to improve tensile, compression, and flexural strength of a composite with a $2 \%$ increase in material weight cost [175]. Markov [203] showed how the distribution of filler particles within the pultruded composites affects their electric characteristics. Recently, Chen et al. [141] experimentally analyzed the influence of activators and initiators on the polymerization process.

Several prepreg types for thermoplastic pultrusion are currently available on the market: preconsolidated tapes (Figure 6a), commingled yarns (Figure 6b), and towpregs 
(Figure 6c) [192,204]. Seeking to optimize thermoplastic pultrusion process, Iftekhar [205] explored the influence of fillers and additives on the viscosity of resins. The relationship between width/thickness of the prepregs and the mechanical and physical properties of composites was studied by Mariatti [206]. Hedayati Velis et al. analyzed the influence of polymer matrix and of a series of prepregs on the mechanical properties of pultruded composites [198].

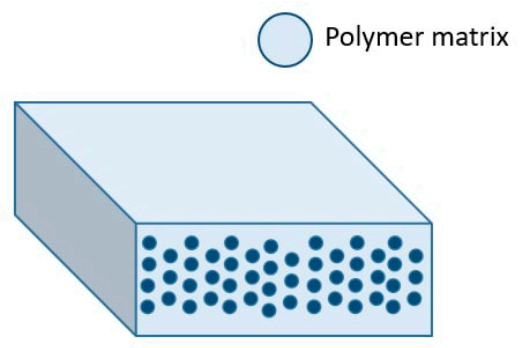

(a)

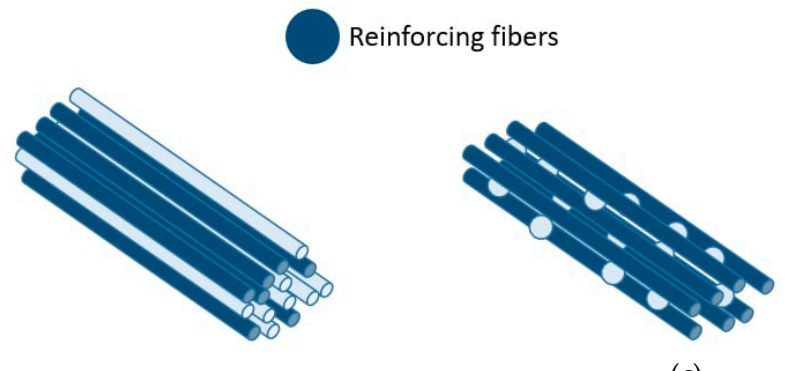

(b)

(c)

Figure 6. Prepregs schemes: (a) preconsolidated tapes, (b) commingled yarns, and (c) towpregs.

\subsection{Preconsolidated Tape}

Preconsolidated tape (PCT) consists of reinforcement fibers impregnated with a thermoplastic polymer at a specific volume fraction. The PCT fabrication method is similar to that of pultrusion - hot thermoplastic melt is injected into the heated die block [192]. The material is then cooled and wound onto reels for storage and transport. Figure 7 shows the schematic illustration of a PCT production machine [192].

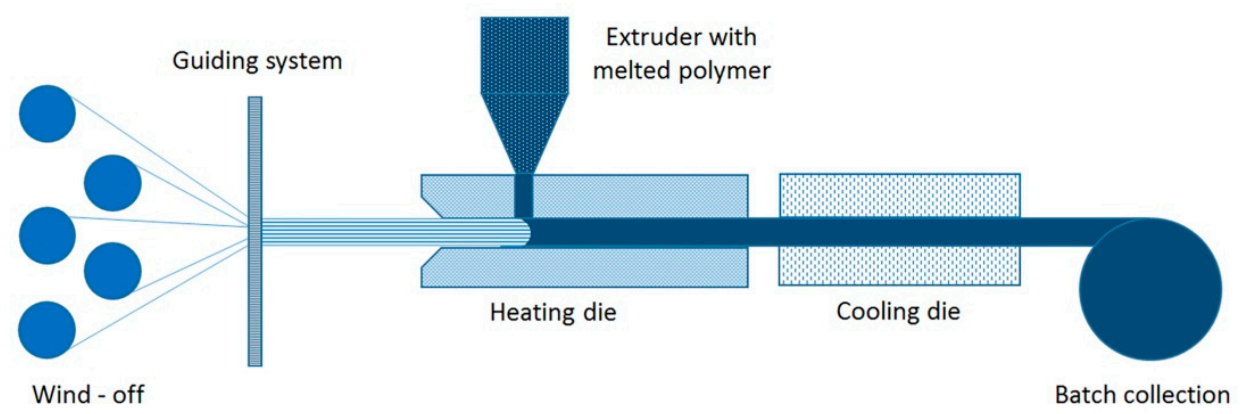

Figure 7. Schematic illustration of a preconsolidated tape (PCT) production machine.

Currently, produced PCT can have widths of up to $300 \mathrm{~mm}$ and thicknesses of $0.125-0.500 \mathrm{~mm}$ [188]. The most popular PCTs are produced with fiber volume fraction of $60 \%$, at the rate of $20-60 \mathrm{~m} / \mathrm{min}$. PCT can be produced in a towpreg production line with the additional heated die installed at the end of the line [194,207].

\subsection{Commingled Yarns (CY)}

Commingled yarns (CY) are composed of intermingled matrix and reinforcement filaments [208]. One of the ways to manufacture $C Y$ is a mixing of fibers during winding with the use of a winding machine (Figure 8) [188]. In CY production it is possible to ensure uniform distribution of matrix and reinforcement filaments over the whole length of prepreg while maintaining the desired volume fraction of reinforcing material [99]. Distribution of filaments plays a very important role, as it affects flexural performance of a composite, its specific weight, and fiber volume fraction in a composite. There are four types of mixed fibers prepregs currently available on the market: commingled, cowrapped, corespun, and stretch-broken yarns [172]. The most popular are commingled yarns [209-213]. Under pressure from thermoplastic melt, reinforcing fibers tend to aggregate during the impregnation and form agglomerations (Figure 10) [213]. 
Matrix forming filaments

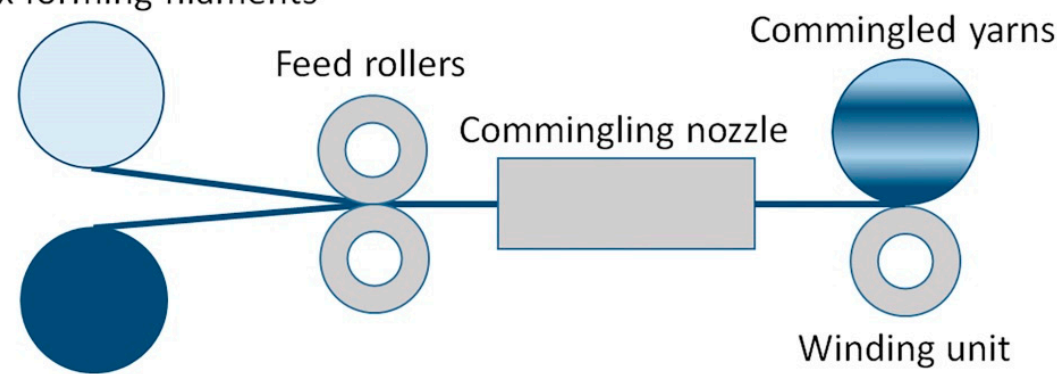

\section{Reinforcing filaments}

Figure 8. Commingled yarn fabrication.

\subsection{Towpregs}

Towpregs fabrication consists in mixing fine-powdered thermoplastic polymer with reinforcing fibers. In dry methods of towpregs fabrication, reinforcing fibers pass through the chamber with powdered polymer and are further fed into the heated chamber where thermoplastic polymer is ultimately joined with reinforcement fibers. In 2000, a pultrusion head for producing towpregs materials was patented at the University of Minho [214]. By convention, towpreg machines consist of five components: fiber creel, guiding system, powder feeder, heating chamber, and winding mechanism (Figure 9) [192]. The powder feeder can utilize various powder agitation systems, such as pneumatic [194], vibration [192], and electrostatic [188]. To handle the problem of high viscosity of thermoplastic melts, the alternative method of wet fabrication can be applied, where a solution of thermoplastic polymer in a solvent is used for impregnation. Reinforcement fibers are impregnated with a solution of thermoplastic polymer and then placed into a heated chamber to evaporate solvent, leaving the neat thermoplastic polymer on fibers. However, as the solvent is quite difficult to remove completely, this can result in increased porosity of the finished composite [188]. Optimization of the towpregs manufacturing process by means of Taguchi's DOE (design of experiments) method was performed by Novo et al. [215]. Nunes et al. [168] studied the influence of pulling speed and furnace temperature on the polymer content in towpregs.

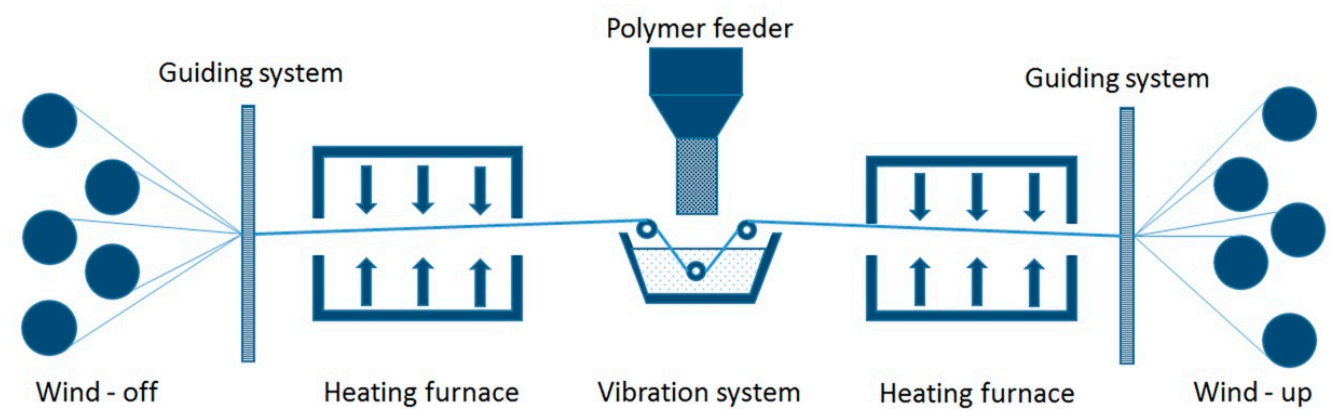

Figure 9. Schematic illustration of a towpreg production machine.

\subsection{Mechanical Properties of Obtained Composites}

Typically, the same standards are used in mechanical testing of thermoplastic and thermoset pultrusion samples. For instance, ASTM D6641-16 is used for compression [216], ISO 527-5 is used for tension [217], ASTM D790-15e2 is used for flexure [218], ASTM D7078/ $7078 \mathrm{M}-12$ is used for in-plane shear [219], and ASTM D2344-16 is used for interlaminar shear testing [220]. For comparison purposes, we have listed some mechanical properties of pultruded thermoplastic (Table 3) and thermoset (Table 4) $[1,30]$ matrix composites. 
Table 3. Mechanical properties of thermoplastic pultruded components.

\begin{tabular}{|c|c|c|c|c|c|c|c|c|c|}
\hline Material & $\begin{array}{l}\text { Volume } \\
\text { Fraction }\end{array}$ & $\begin{array}{c}\text { Pultrusion } \\
\text { Speed, } \mathrm{m} / \mathrm{min}\end{array}$ & $\begin{array}{c}\text { Flexural } \\
\text { Strength, MPa }\end{array}$ & $\begin{array}{c}\text { Flexural } \\
\text { Modulus, GPa }\end{array}$ & $\begin{array}{c}\text { Tensile } \\
\text { Strength, MPa }\end{array}$ & $\begin{array}{c}\text { Elastic Modulus, } \\
\text { GPa }\end{array}$ & $\begin{array}{l}\text { Notched Izod Impact } \\
\text { Strength, } \mathrm{J} / \mathrm{m}^{2}\end{array}$ & $\begin{array}{l}\text { Interlaminar Shear } \\
\text { Strength, MPa }\end{array}$ & Reference \\
\hline GF/Nylon 12 & 0.50 & $0.3-3.0$ & $380-610$ & - & - & - & - & $15-40$ & [162] \\
\hline GF/Nylon 6 & $0.71-0.75$ & $0.1-0.9$ & $359-469$ & - & $828-869$ & - & $1868-2348$ & - & [199] \\
\hline GF/PPS & $0.70-0.75$ & $0.1-0.9$ & 965 & - & 793 & - & - & - & [199] \\
\hline GF/PMMA & 0.75 & $0.1-0.9$ & $656-863$ & - & 897-1035 & - & $1815-2188$ & - & [199] \\
\hline $\mathrm{GF} / \mathrm{PBT}$ & $0.38-0.41$ & $0.1-1.2$ & - & - & - & - & - & - & [144] \\
\hline $\mathrm{GF} / \mathrm{PP}$ & 0.35 & $0.01-1.5$ & $465-485$ & $22-24$ & - & - & - & - & {$[94,95]$} \\
\hline $\mathrm{GF} / \mathrm{PP}$ & 0.37 & $0.2-0.3$ & $571-620$ & $24-28$ & $516-597$ & $24-26$ & - & $25-28$ & [192] \\
\hline $\mathrm{GF} / \mathrm{PP}$ & $0.53-0.59$ & 0.9 & $113-121$ & 22 & 279-331 & $27-33$ & - & - & [194] \\
\hline GF/PP & 0.52 & $0.2-0.3$ & $146-170$ & $27-29$ & 314-358 & $32-35$ & - & $7-8$ & [192] \\
\hline GF/PMMA & - & 0.4 & 414 & - & 720 & - & 2400 & - & [221] \\
\hline GF/PMMA & - & 0.7 & 207 & - & 530 & - & 1300 & - & [221] \\
\hline GF/PMMA & - & 1.0 & 100 & - & 410 & - & 700 & - & [221] \\
\hline $\mathrm{GF} / \mathrm{PA} 6^{*}$ & 0.70 & 0.8 & $800-1060$ & $26-34$ & - & - & - & $61-70$ & [154] \\
\hline $\mathrm{GF} / \mathrm{PU} *$ & 0.50 & 2.7 & 210 & 6 & - & - & - & - & [222] \\
\hline CF/PEEK & 0.55 & $0.06-0.6$ & $1150-1380$ & $108-130$ & - & - & - & - & [143] \\
\hline CF/PPS & 0.58 & $0.1-0.9$ & 1365 & - & 1172 & - & 1601 & - & [199] \\
\hline $\mathrm{CF} / \mathrm{PP}$ & 0.32 & $0.2-0.3$ & $155-163$ & $36-40$ & - & $196-213$ & - & 14 & [192] \\
\hline $\mathrm{CF} / \mathrm{PP}$ & 0.55 & $0.2-0.3$ & $222-243$ & $86-91$ & - & $100-116$ & - & $12-13$ & [192] \\
\hline Flax/PLA & 0.40 & $0.5-0.7$ & 65-115 & $5-8$ & $15-75$ & $6-8$ & - & - & [99] \\
\hline Graphite/PEI & 0.61 & 0.18 & 1150 & 103 & - & - & - & - & [196] \\
\hline Graphite/PPS & 0.61 & 0.08 & 1770 & 131 & 1820 & 117 & - & - & [197] \\
\hline
\end{tabular}


Table 4. Mechanical properties of thermoset pultruded components.

\begin{tabular}{cccc}
\hline Material & Volume Fraction & Tensile Strength, MPa & Elastic Modulus, GPa \\
\hline GF/Polyester & $0.5-0.8$ & $307-1320$ & $21-59$ \\
GF/Vinylester & 0.6 & 240 & $18-42$ \\
GF/Epoxy & 0.5 & $414-790$ & $32-40$ \\
CF/Vinylester & - & 1400 & $140-145$ \\
CF/Epoxy & $0.5-0.6$ & $1213-2200$ & $130-180$ \\
\hline
\end{tabular}

\subsection{Durability of Thermoplastic Pultruded Materials}

If we want pultruded thermoplastic profiles to be widely used, then we need be sure of their durability. Unfortunately, durability of both thermoset [223] and thermoplastic pultrusion has not been studied deeply enough. Articles published are mostly related to topics other than pultrusion technology. We intend to analyze reaction injection molding and press molding in brief in order to attract scholars' and engineers' attention to thermoplastic pultrusion durability.

Under microorganism actions, the molecular structure of a polymer can biodegrade and both physical and chemical properties can also change. Polymers can be the source of energy for the microorganisms [224]. The molecular bonds can be destroyed, as well as the composite's properties. Biodegradation depends on crystallinity, temperature, $\mathrm{pH}$ of the environment, humidity, molecular weight of the polymer, various additives with enzymes, and bioorganisms [225]. Not all plastics are biodegradable, only some, such as polyvinyl alcohol (PVA), polycaprolactone (PCL), polyester, polylactide (PLA), polyethylene, nylon, polyhydroxybutyrate (PHB), and polyglycolide (PGA) [226,227]. Some composites are nonsusceptible to the process of biodegradation; thus, starch polymers [228-235] and fish waste [236] additives are used to accelerate the process. Composite materials based on natural fibers can be of great interest as they fully recycle through biodegradation. Moreover, biocomposites can be recycled in composting conditions [224,233,237]. Reinforcements based on wood [238], aspen [239], flax, hemp, sisal [240], cellulose [241], pineapple leaves [242], and reed [243] are typically applied. Degradation rate depends on the structure of the natural fibers, like the flexural strength of composites based on nonwoven mat decreases more than that of a woven composite [237].

Although the reaction of polymerization in thermoplastics composites is complete, the shelf life of the polymers is virtually unlimited [51-57]. The degradation of material properties may occur over time due to fatigue loads, temperature exposure, humidity, chemical reactions, radiation, etc. For example, fatigue provokes fiber failure, matrix cracking, interface debonding [244], and decrease in material strength [245].

Polymers behave differently depending on heating conditions and temperatures. Fatigue strength decreases faster at cryogenic temperature comparing with room temperature [246]. Long-term aging of composite material at a temperature below melting causes a change in glass transition temperature and strength [247,248]. During short-term aging, thermoplastic composite is sharply heated to thermal decomposition temperature; thus, rapid decrease in tensile and interlaminar shear strength is observed [249,250]. Apart from debonding and cracks, delamination and fiber failures can occur [251,252]. Freeze and thaw cycles, accompanied by cooling the material below $0{ }^{\circ} \mathrm{C}$, lead to loss of flexural strength and Young's modulus [253].

Water immersion and exposure to humidity affects tensile, compression, and flexural strength [254]. Mechanical properties depend on the temperature of the surrounding medium [254]. Typically, thermoplastic composites are studied in seawater [254-256], tap water $[257,258]$, etc. Acid and harsh environments negatively affect the molecular bonds and mechanical characteristics of the polymers [259]. Various gases, such as air, air under pressure, and nitrogen, reduce the strength of composites [260].

Research on thermoplastic pultruded material behavior, when placed in a different harsh environment, is needed if we want wide use of profiles in marine and chemical engineering. Nuclear engineering is interested in the study of reactive radiation effects. 
Durability of both matrix and fiber reinforcement is to be studied as well. Experiments conducted at high and low temperatures are needed to apply the thermoplastic pultruded profiles for civil engineering in different climatic zones.

\subsection{Future Trends}

The properties of the pultruded profiles depend greatly on the choice of raw materials. The lack of knowledge in the field of thermoplastic pultrusion becomes apparent in the choice of raw materials, as opposed to the thermoset pultrusion. To popularize the application of thermoplastic pultrusion, we need better understanding of physical phenomena taking place during the manufacturing process, and their dependence on the choice of raw materials, and clearer understanding of the influence raw materials have on mechanical performance and the life cycle of thermoplastic composite materials and structures. This subchapter will briefly discuss the most promising areas of research, from the authors' point of view.

In spite of availability of several studies on the influence of raw materials on mechanical performance of pultruded thermoplastic composites and structures, we believe that more research is necessary in order to study this question. Of special importance here are the studies of stress-strain state in composite materials under different modes and rates of loading.

An in-depth research of existing and perspective additives is necessary to better understand their influence on the properties of end products and to improve mechanical performance and physical properties of pultruded thermoplastic profiles. Currently, only the studies by Markov [203] and Chen et al. [141] are available in this field. In addition, there is an obvious lack of studies on the influence of micro- and nanoadditives, both in thermoset pultrusion (Kuruvilla and Renukappa [261], Manjunath et al. [262]) and in the thermoplastic one (Roy et al. [263], Alam et al. [264]).

Striving to reduce environmental footprint, human society demonstrates ever increasing interest in sustainable development and the use of natural materials, and the composite industry is no exception. Application of biocomposites is currently one of urgent research topics in thermoplastic materials [265-270]. Broad introduction of such composites into everyday life will obviously require extensive study of their properties and characteristics.

While the influence of additives improving UV-aging performance and corrosion resistance of end products is mostly well understood for the thermoset pultrusions, this is not the case for the thermoplastic ones. Therefore, the real application of thermoplastic composites will require extensive studies of their behavior in the presence of various additives, which might be of special interest for the industrial and scientific community. In addition, of great interest for the composite community is the influence of nonbiodegradable and flame-retardant compounds on the properties of thermoplastic materials.

The use of hybrid reinforcements (e.g., the simultaneous use of glass and carbon reinforcing fibers) is currently one of the hottest topics, since some loaded parts of pultruded structures may benefit from the use of different fiber types. However, there is a lack of knowledge on this issue both in thermoset [271] and, particularly, in thermoplastic pultrusion.

\section{Process Modeling}

Manufacturing of pultruded thermoplastic composites depends on various process parameters such as preheater temperature, heated die geometry, temperature and pressure inside a heated die, cooling die temperature, pulling speed, and pulling force, and, thus, necessitates the development of mathematical models for process optimization. In addition to process parameters, the properties of prepregs, such as melting temperature, glass transition temperature, coefficient of thermal expansion, etc., should also be taken into account. All things considered, mathematical models should allow an engineer to determine the degree of impregnation, temperature distribution, pulling force, etc., for complex profile geometries. These models, based on modern methods, would allow calculation of residual stresses in a composite, making it possible to predict cracking, warping, shrink- 
age, and other process-induced deformations. Among the published articles and books on mathematical modeling in thermoplastic pultrusion, of particular interest is the book by Suresh Advani and Murat Sozer [272]. Currently, several studies of residual stresses and strain are underway in the field of thermoset pultrusion [30,171,273-275], while the number of similar studies for thermoplastic pultrusion is significantly lower. An overview of existing mathematical models of nonreactive thermoplastic pultrusion follows.

\subsection{Impregnation}

Properties of final products depend on the fiber volume fraction. The volume fraction and strength of material, in turn, depend on fiber impregnation [276] impeded by the high viscosity of thermoplastics. Several mathematical models were developed to find optimum manufacturing conditions and to investigate the relationship between the degree of impregnation and process parameters. Most of these models describe the nonreactive thermoplastic pultrusion with commingled yarns and are based on the following approximations:

- Reinforcing fibers are represented by separate groups (agglomerations) in the thermoplastic melt (Figure 10);

- These groups have an elliptical or circular section;

- Fibers are impregnated uniformly over the bulk of the product on all sides.

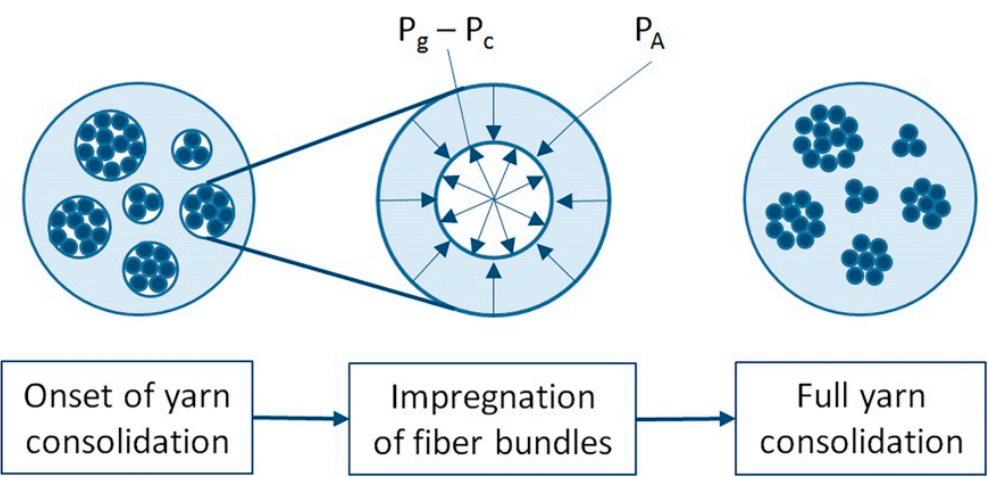

Figure 10. Schematic illustration of yarn section and consolidation process; $\mathrm{Pg}$-pressure from the void, $\mathrm{Pc}$-capillary pressure, $\mathrm{P}_{\mathrm{A}}$-applied pressure.

The aim of these models is to determine the degree of impregnation at any moment of time and to estimate the void content $[209,213]$. The motion of thermoplastic melt through fibers is governed by Darcy law describing the flow of fluid through a porous medium [277]:

$$
u=-\frac{K}{\mu} \nabla p,
$$

where $u$ — the speed of fluid motion inside fibers, $K$ — fiber permeability tensor, $\mu$-viscosity, $\nabla$-nabla operator, and $p$-external pressure.

Taking into account the fiber volume fraction and local speed of fibers and thermoplastic melt, Bernet et al. [213] obtained the following expression for Darcy law:

$$
\left(1-V_{f}\right)\left(u_{l}-u_{s}\right)=-\frac{K}{\mu} \nabla p,
$$

where $V_{f}$-fiber volume fraction, $u_{l}$ and $u_{s}$-local speeds of thermoplastic melt and fiber, respectively. 
As the permeability $K$ is not constant and uniform in all directions, the impregnation process is difficult to model. In order to calculate permeability in the direction parallel to fiber orientation, the Kozeny-Carman equation is used [211]:

$$
K_{\|}=\frac{r_{f}^{2} \cdot\left(1-V_{f}\right)^{3}}{4 \cdot k_{0} \cdot V_{f}^{2}},
$$

where $r_{f}$-fiber radius, $V_{f}$-instantaneous fiber volume fraction depending on the pressure, and $k_{0}$-the permeability constant.

To determine permeability of fibers in transverse direction, the equation proposed by Gutowski et al. is used [278]:

$$
K_{\perp}=\frac{r_{f}^{2}\left(\sqrt{\frac{V_{a}}{V_{f}}-1}\right)^{3}}{4 k_{0}\left(\frac{V_{a}}{V_{f}}+1\right)},
$$

where $V_{a}$-maximum possible fiber volume fraction and $k_{0}$-the permeability constant.

When modeling the impregnation process during pultrusion, one should consider the motion of matrix along the fibers. Kim et al. [212] proposed the micromodel describing the impregnation of fibers in a transverse direction, and the macromodel describing the lengthwise flow of matrix. The macromodel was based on Darcy law and the KozenyCarman equation. Later, the model was supplemented with mass conservation equations in a cylindrical coordinate system (Equation (5) for matrix, and Equation (6) for fiber reinforcement):

$$
\begin{gathered}
\frac{\partial}{\partial t}\left(1-V_{f}\right)+\frac{1}{r} \frac{\partial}{\partial r}\left(\left(1-V_{f}\right) r u_{l}\right)=0, \\
\frac{\partial}{\partial t} V_{f}+\frac{1}{r} \frac{\partial}{\partial r}\left(V_{f} r u_{s}\right)=0,
\end{gathered}
$$

where $r$-matrix propagation front.

Koubaa et al. $[279,280]$ have developed a pultrusion impregnation model based on the Navier-Stokes equation, having the following expression in a cylindrical coordinate system:

$$
\frac{\partial P}{\partial z}=\frac{\mu}{r} \frac{\partial}{\partial r}\left(r \frac{\partial u_{z}}{\partial r}\right),
$$

where $z$-coordinate axis coinciding with the pulling direction and $u_{z}$-fluid motion speed along the longitudinal axis. The following boundary conditions are imposed: zero component of fluid motion speed outside fibers, and equality of fluid motion speed inside fibers and of the pulling speed.

The model proposed by Gibson et al. [281] takes into account the capillary force. Sala and Cutolo [163] conducted numerical and experimental studies and proposed the model that uses both Newtonian and power-law relationships to predict the impregnation process outcomes. At the same time, Haffner et al. [282] developed a mathematical model that describes the microscopic flow of resin and accounts for different fiber arrangements, volume fraction of reinforcement, and impregnation time. Miller et al. [38] proposed the impregnation model for a composite material based on towpregs. The model represents a cell consisting of three filaments with two thermoplastic particles incorporated in spaces between filaments. Melting thermoplastic particles impregnate the filaments and fill the space between them. The proposed model considers the external pressure exerted by the fiber bed, capillary pressure, viscous pressure resulting from matrix motion, and springing pressure from fiber compaction. The resulting equation for impregnation time accounts for filament diameter and the size of particles, assuming them constant over the whole bulk of material. Results obtained with the analytical model are close to the experimental data, demonstrating good accuracy of the model. Subsequently, Bechtold et al. [283] proposed 
two different methods to model the impregnation process in the case of thermoplastic pultrusion with braided commingled yarns. Koubaa et al. [284] studied the impregnation of a single glass-fiber bundle and proposed the model based on the Young-Laplace law that takes into account the influence of capillary force. Ngo et al. [285] proposed a model of thermoplastic pultrusion with carbon fiber-reinforced prepreg that accounts for a multiscale 3D impregnation die.

\subsection{Temperature Distribution}

The thermal model makes it possible to determine the distribution of temperatures over the heated die and the degree of crystallinity of a thermoplastic polymer. All developed models rely on the heat transfer equation adapted to the pultrusion process, which results in introduction of a pulling speed term on the left side of the following equation [286]:

$$
\rho C V \frac{\partial T}{\partial x}=\frac{\partial}{z}\left(k \frac{\partial T}{\partial z}\right)+Q,
$$

where $\rho$-specific density, C-specific heat capacity, $V$-pulling speed, $x$-coordinate axis parallel to the die block axis, $z$-coordinate axis perpendicular to the die block axis, $T$-temperature, and $Q$ - energy released during crystallization. Most polymers are amorphous and do not form a crystal lattice [286], making it possible to disregard the $Q$ variable in most cases.

Using the model proposed by Åstroöm and Pipes [169,287], Babeau [288] conducted the experimental test and numerical simulation, and obtained results that are very close to the analytical model. Carlsson [96] proposed the following expression for the energy released during crystallization of polypropylene:

$$
Q=m \frac{\partial \alpha}{\partial t} H
$$

where $m$-mass fraction of a polymer matrix, $\alpha$-degree of crystallinity, and $H$-theoretical ultimate heat of crystallization at $100 \%$ crystallinity.

The crystallization process can be divided into two stages. The first stage is the formation of primary nuclei. The second stage is the growth of a crystal formed on the nuclei. Thus, the derivative of the degree of crystallinity can be expressed as follows [96]:

$$
\frac{\partial \alpha}{\partial t}(T, \alpha)=\left(f_{1}(T)+f_{2}(T) \alpha\right)(1-\alpha),
$$

where the $f_{1}$ function accounts for formation of primary nuclei and $f_{2}$ accounts for further growth of the crystal. Expressions for $f_{1}$ and $f_{2}$ were proposed by Malkin [289]. In addition to analytical methods, scientists often use numerical methods to determine the degree of crystallinity and the heat transfer, as explained by Haffner et al. [290]. Trying to minimize modeling oscillations in the case of high pulling speed and rough mesh, Ruan et al. [291] developed a 2D thermal model of thermoplastic pultrusion. Subsequently, Yn et al. [142] utilized the finite difference method to predict temperature and reaction evolutions within the pultruded profile and to optimize process parameters while maximizing the thickness of pultruded profile. Nejhad [148] proposed and verified experimentally a numerical model dealing with thermal analysis of impregnated tows/tapes in thermoplastic pultrusion. Numerical modeling providing information on both temperature distribution within a profile during pultrusion and crystallization kinetics of the polymer was proposed by Carlsson and Astrom [292]. Ahmed et al. [293] applied the FE-NCV (finite element-nodal volume control) approach to determine the heat distribution over the heated die block and to calculate the degree of crystallinity. Aside from Ahmed, Joshi and Lam [294] used the same modeling approach to investigate crystallization in a composite based on carbon fibers and PEEK polymer (CF/PEEK) specimen. 


\subsection{Pressure and Pulling Force}

Åstroöm [287] proposed a model describing the distribution of pressure over the heated die and the model of pulling force. He used the integral relationship between the pulling force and the drag over the unit area, expressed in the following form:

$$
f_{\text {tot }}(x)=(1-\Omega(x)) f_{v}(x)+f_{\mathcal{c}}(x)+\Omega(x) f_{f}(x),
$$

where $\Omega(x)$-the part of a composite subjected to pressure, $f_{v}(x)$-viscous drag for Carreau fluid, $f_{c}(x)$-compaction resistance resulting from fibers compaction in the tapered portion of the heated die block, and $f_{f}(x)$-friction resistance.

The model [287] uses the Carreau model and considers the nonlinear nature of thermoplastic melt viscosity:

$$
\eta_{a}=\eta_{0}\left(1+(\lambda \gamma)^{2}\right)^{\frac{n-1}{2}}
$$

where $\eta_{0}$-zero-shear rate viscosity, $\gamma$-shear rate, $\lambda$-indicates the shear rate at which shear-thinning effects become significant, and the dimensionless constant $n$ describes the degree of shear thinning. The comparison of results obtained with the analytical model and experimental data can be found in [155].

Lee et al. [286,295] proposed a numerical model to predict pressure and pulling force, as well as temperature and crystallinity. Simultaneously, a model predicting pulling resistance from the die, together with temperature and pressure distribution within a composite was developed by Astrom and Pipes [155,296]. Parasnis et al. [297] studied the influence of viscosity and shear load on the pulling force. They used a finite element model and compared calculated pulling force values with experimental data. The authors reported a discrepancy between experimental and calculated data, appearing after a certain value of pulling speed was reached. While the model predicted an exponential increase in pulling force, the experiments demonstrated that the increase in pulling force takes place until a certain pulling speed value was reached; after reaching this value, the pulling force remained unchanged. Blaurock and Michaeli proposed a method predicting pulling force and then compared it with experimental data [298]. Stavrov and Tsvirko [179] analyzed the relationship between pulling force and viscous characteristics.

\subsection{Future Trends}

Existing impregnation, and temperature and pressure distribution models rely on a series of approximations allowing a determination of process parameters for simple profile and die shapes, and mostly for commingled yarns. However, modeling of thermoplastic pultrusion for complex cross-sections, towpregs, and PCT still remains an open issue. Thermoplastic pultrusion cannot boast significant progress in mathematical modeling as opposed to the thermoset pultrusion, where it widely applied, first, to model complex shaped profiles (L- and I-shaped sections [274], wind turbine blades [299,300], etc.) with complex reinforcement lay-ups, and, second, to develop algorithm for their optimization [301-317]. In recent years, a significant interest to optimization has been observed in the scientific and engineering community. Optimization tools allow engineers to solve a large number of problems, from pultrusion process optimization to optimization of raw materials for pultruded profiles, and to take full advantage of composite materials. However, in spite of certain advances in optimization, there is, still, a lack of knowledge and experience on multiobjective optimization, both in thermoplastic and thermoset pultrusion. Aside from process parameters optimization, multiobjective optimization makes it possible to optimize the geometric topology of composites [318]. Modern mathematical models should allow a solution of process optimization problems with large number of input parameters. Moreover, modeling methods may help researchers investigate residual stresses in a composite, and their influence on cracking, delamination, warpage, shrinkage, and other processinduced defects $[171,275]$. The authors believe that expanding the use of supercomputers will bring the problems of mathematical modeling and optimization of composites to a 
fundamentally new level. Thus, aside from solving problems discussed earlier, the growing computational power will allow us to explain and model macrobehavior of composite materials, based on their microscale parameters.

\section{Application}

\subsection{Pultrusion Market}

The pultrusion market demonstrates steady growth from year to year. According to the European Pultrusion Technology Association (EPTA) forecast [319], the pultrusion market is expected to reach the mark of $€ 100$ billion in 2022. This growth opens new opportunities both for the thermoset and thermoplastic pultrusion. Thermoplastic pultrusion steadily gains popularity along with the thermoset one, although at a slower pace. For the sake of comparison, the entire thermoplastic composites market, including, aside from pultrusion, all the other thermoplastics applications as well, is expected to grow from $€ 22.2$ billion in 2020 to $€ 31.8$ in 2025, according to the report titled "Thermoplastic Composites Market by Resin Type (Polypropylene, Polyamide, Polyetheretherketone, Hybrid), Fiber Type (Glass, Carbon, Mineral), Product Type (SFT, LFT, CFT, GMT), End-Use Industry, and Region-Global Forecast to 2025" [320]. The main factor limiting the application of thermoplastic pultrusions is the price, i.e., the availability of thermoplastic resins, since they cost more than those used in thermoset pultrusion. This is one of the factors restraining the growth in thermoplastics applications [320]. Therefore, lower production costs, and, thus, lower final price of the manufactured products could stimulate the demand for thermoplastic profiles, offering competition to thermoset profiles, although both reports should be considered in the context of coronavirus (SARS-CoV-2) COVID-19 pandemic situation. To illustrate, in November 2020, the Federation of Reinforced Plastics reported a 12.7\% drop in production of glass-fiber-reinforced plastics in Europe, reaching the mark of 996,000 tons in 2020, which is the steepest drop since the global economic crisis of 2008-2009 [321]. According to the same report, pultrusion production volumes in 2020 plunged by $10.7 \%$, making the pultrusion industry the least affected by the crisis, when compared to all other composite sectors.

\subsection{Patents}

According to registered patents, one of the most common applications of thermoplastic pultrusion are thin [322-325], round, and rectangular profiles. Typically these cross-sections are utilized as wires [326,327] and their coatings [328], rods [329-331], pipes [332,333], and hollow profiles $[334,335]$ used in the production of doors and windows $[336,337]$, etc. Global IP Holding Co. LLC patented the method to produce parts of sandwich structures $[338,339]$ using the pultrusion process. They also patented constructions that combine both metal elements and composite materials [340,341]. Various combinations of fiber structures are used; for example, some of the layers are made of unidirectional fibers [342], while the others are made with transversely oriented fibers [343], fabrics [344,345], or long-fiber thermoplastics (LFTs) [346]. Pultruded profiles are widely used in railway construction. A group of engineers from Pultrusion Technique Inc. developed a method for the production of rail clamps, providing the benefit of excellent corrosion resistance [347], as compared to their iron counterparts. In addition, they patented wavy profiles [348] and elements with asymmetrical shapes [349,350].

\subsection{Current Applications of Thermoplastic Pultruded Profiles}

Pultruded thermoplastic profiles effectively combine properties of thermoplastic composites with advantages of pultrusion as a manufacturing process. Offering improved toughness and fire resistance, thermoplastic composites find application in many industries. Pultruded thermoplastic composites have found wide application in aerospace and $[67,69]$ aviation $[64,66]$ engineering. For example, landing gear doors made of thermoplastic composites have lower weight, compared to their aluminum counterparts, are weldable, and can be recycled, as opposed to those made of thermoset composites [68,351]. Thermo- 
plastic composites can be used to manufacture airplane flooring [68], ice protection panels protecting the fuselage [351], various interior elements [351], rivets for fastening [15,65], aircraft wings [68], radomes [68], and flaps [68]. Aside from aviation, thermoplastic composites are widely used in the automotive industry $[59,60,62,63]$. The thermoforming ability of thermoplastics allows fabrication of various complex shape parts, such as dashboard carriers [61], body structures [61], bumpers [58,61,352], wheel rims [353], and seat structures [61] (commonly produced from long-fiber thermoplastics (LFT) [354]), etc. In civil engineering $[70,71]$, thermoplastic composites are used to manufacture airfoils for wind turbine blades [355], pipes [84,85], rebars [86,87] and rods [88-91], reinforcement for concrete structures [86], window profiles [83], elements of walls [72], flooring [72], exterior siding [72], and roofing systems [72,73]. In addition, composite poles used in powerline-supporting structures for energy grids are often produced by thermoplastic pultrusion [74]. Moreover, pultruded elements can be used in restoration of deteriorated structures and rehabilitation projects [75]. Aside from these applications, there is a demand from the marine $[76-79,356]$ and oil/gas [80] sectors. In view of product recycling capabilities, thermoplastic pultrusion is the process of choice for production of semiproducts for LFT [357-363] and cork and pellet composites [364-368]. Pultrusion can produce prepregs for constant size LFT with specified length of fibers and precisely maintained fiber volume fraction.

In spite of a steady growth in application of thermoplastic pultrusions in auxiliary elements of structures in the last few years, there are no published articles, patents, or news on the application of such profiles in the design and construction of full-scale bearing structures, such bridges, cooling towers, etc. This can be explained by the lack of knowledge on the behavior of these types of structures, which are produced of thermoplastic pultruded elements. Scientists and engineers have yet to investigate the strength, buckling, creep, fatigue, and durability aspects of thermoplastic pultruded profiles as applied to the fullscale structures.

Advances and experience in implementation of such structures are almost completely lacking, as there are no relevant design codes. European [369-371] and US [372] design codes regulating the design of pultruded structures deal only with thermoset profiles, or have no clear mention of pultrusion type. Therefore, these design codes can only be freely applied in the design of thermoset pultruded structures, as they were specifically developed for these types of profiles. The peculiarities of thermoset and thermoplastic pultrusion processes will undoubtedly impose certain limitations on the behavior of profiles under a particular loading mode. The behavior of thermoplastic and thermoset profiles under the same load may differ significantly. Thus, to account for specifics of thermoplastic profiles, existing structural design codes should be revised or rebuild anew. This will require extensive experimental investigations, the results of which will be used as a basis for future design codes.

\subsection{Future Trends}

Advanced studies mentioned in this subchapter show that pultruded thermoplastic profiles can be applied both in traditional areas mentioned previously, and in some, at first sight, nonconventional ones. The authors believe it is important to draw the attention of the composites research community to these perspective fields of research.

Application of green technologies and materials in manufacturing is a hot topic both in the composite community and in other industries [373]. Multiple studies conducted in the last few years demonstrate that human society should do its best to thoughtfully use and recycle the products of its activity, and to minimize its carbon footprint. Recent studies in recycling of thermoplastic composites demonstrate the growing interest to this field. There are various mechanical, chemical, and thermal approaches to composites recycling. The main problem associated with the application of recycled composites lies in a degradation of mechanical properties of recycled fibers to be used in newly produced composites $[374,375]$. On the other hand, striving to minimize carbon footprint, researchers opened a new perspective on the application of polyethylene terephthalate (PET), typi- 
cally used in worldwide packaging, as a raw material for thermoplastic pultrusion [187]. Thus, any investigations aimed at application of recycled and natural raw materials in thermoplastic pultrusion will have a good perspective.

The application of thermoplastic polymers in composites holds considerable promise for the use of welded joints; however, the performance of such joints is yet poorly understood and will require the analysis on a case-by-case basis. In spite of the large number of publications in a field of thermoplastics welding in general [376-379], there are no studies on the welding of pultruded thermoplastic composites in particular.

There are a few studies reporting on the medical application of thermoplastic pultruded profiles. Tanimoto et al. [380,381] manufactured and investigated the properties of pultruded glass-fiber-reinforced polycarbonate wiring for orthodontic applications. Engineers from Fraunhofer Institute for Production Technology developed the process allowing a pultrusion of thermoplastic elements as small as $1 \mathrm{~mm}$ in diameter, which can be used in medical applications [382,383]. Authors report the excellent compatibility with magnetic resonance imaging (MRI) techniques and good post formability. Thermoset pultrusion was used to fabricate guidewire appliances that were mechanically tested along with in vivo experiments on animals [384]. In addition, the appliance compatible with magnetic resonance (MR) was pultruded and tested in various MR-guided cases aimed to study the behavior of arteries [385]. Recently, an experimental study [386] demonstrated the feasibility of thermoset micropultrusion of $280 \mu \mathrm{m}$-diameter carbon fiber elements, and proposed the use of thermoplastic matrices as a recommendation for further research.

Invented in ETZ Zurich, continuous lattice fabrication (CLF) is a new additive manufacturing (AM) technique making it possible to print thermoplastic fiber reinforced polymers (FRPs) in three-dimensional space at any imaginary trajectory, with the help of robotic arms [387-389]. This approach combines both extrusion and pultrusion. Introduction of $\mathrm{AM}$ or robotic fabrication techniques into thermoplastic pultrusion manufacturing would definitely broaden the perspectives for thermoplastic pultrusion. Meanwhile, a novel technique proposed by the Institute of Plastics Processing at RWTH Aachen University presents hybrid pultruded profiles combining both a thermoset core and thermoplastic top layer, combining the advantages of both processes [390]. Combination of thermoplastic and thermoset pultrusions may certainly result in more efficient structural components, thereby exploiting the advantages of both manufacturing techniques.

As the human society demonstrates the increasing interest in colonization of Moon and Mars, there will be a large demand for space transport technologies and to produce various structures for space stations, power generation platforms [391], and other facilities necessary to settle on other planets. There are no considerable obstacles to shipping a pultrusion machine into space [3] to utilize the advantages of thermoplastic polymers [392,393]. British company Magna Parva, specializing in space research, plans to use pultrusion in space where no kind of production has been done before [394].

Typically, pultruded profiles are supposed to have straight shapes; however, pultrusion of nonlinear profiles can be accomplished as well. Curved pultruded profiles can be used to minimize the excessive deflection of structures, to implement components of complex shapes, or to impart individuality to architectural forms. Currently, fabrication of curved pultruded profiles is actively investigated in thermoset pultrusion [395-397]. However, similar studies in thermoplastic pultrusion are very limited [398], and, therefore, this issue requires further investigation.

According to the studies on urban planning and development, over $70 \%$ of world population will live in cities by 2025. Steadily growing migration from countryside to the cities forces telecom companies to search for solutions to today's technology challenges. Large megapolises require effective and innovative information services and data transmission facilities. Offering data rates of 10-20 Gbps, 5G may be a solution to these problems [399]. Pultruded profiles, being transparent to radio frequency signals, are perfectly suited for use in the growing 5G network infrastructure around the globe [399]. 
In addition, the growing interest in smart polymers, materials able to change their physical and chemical properties under the influence of various external factors $(\mathrm{pH}$, temperature, UV light, etc.) [400], may also apply to thermoplastic pultrusion. Of special interest are shape memory polymers, a subset of smart polymers, which are able to recover their shape under the influence of certain external factors [401,402]. These materials with their unique properties can have various applications -in medicine [403] and self-healing systems [404], and in aerospace [405], electronic [403] and civil [403,406] engineering.

\section{Conclusions}

This study reviews the state-of-the-art in thermoplastic pultrusion. We discussed the distinctive features of the process, materials used, patents registered, properties of pultruded profiles, industrial market situation, and applications of thermoplastic pultruded profiles. Application of thermoplastic polymers in pultrusion instead of thermoset ones makes it possible to improve the impact strength of structures, and offers the advantages of recycling, indefinitely long storage of source material, and application of welded joints of composite profiles. However, the limited number of studies in the field of pultruded thermoplastic composites makes it difficult to unveil the full potential of thermoplastic pultrusion. Trying to answer the question of the huge industrial, scientific, and experience gap existing between thermoset and thermoplastic pultrusion, we were able to develop recommendations on further research in the application of composite structures in general, and pultruded thermoplastic profiles in particular. We also recommend the research areas necessary to broaden the field of thermoplastic profiles application in order to obtain the knowledge sufficient for understanding the complex mechanics of thermoplastic composites, which is necessary to design complex critical structures currently built of thermoset profiles.

It must be noted that this review, being the first of its kind (as no review papers on thermoplastic pultrusion were published earlier), discusses only general questions and does not probe deeper into specific aspects of thermoplastic pultrusion and the materials produced. However, as there is an urgent need for such studies, in the near future we can expect publication of separate review papers concerning specific subtopics of thermoplastic pultrusion, such as, for instance, additives, structural design, durability of pultruded thermoplastic elements, process-induced shape distortions, biocompatibility, and natural materials, among others.

Author Contributions: Conceptualization, A.S., I.A., A.V., and K.M.; methodology, A.S., A.V., and K.M.; writing—original draft preparation, K.M., A.V., and A.S.; writing-review and editing, K.M., A.V., and A.S.; visualization, K.M.; supervision, A.S.; project administration, A.S.; funding acquisition, I.A. All authors have read and agreed to the published version of the manuscript.

Funding: This research did not receive any specific grant from funding agencies in the public, commercial, or not-for-profit sectors.

Conflicts of Interest: The authors declare no conflict of interest.

\section{References}

1. Vedernikov, A.; Safonov, A.; Tucci, F.; Carlone, P.; Akhatov, I. Pultruded materials and structures: A review. J. Compos. Mater. 2020, 54, 4081-4117. [CrossRef]

2. Bakis, C.E.; Bank, L.C.; Brown, V.L.; Cosenza, E.; Davalos, J.F.; Lesko, J.J.; Machida, A.; Rizkalla, S.H.; Triantafillou, T.C. Fiber-reinforced polymer composites for construction-State-of-the-art review. J. Compos. Constr. 2002, 6. [CrossRef]

3. Starr, T.F. Pultrusion for Engineers; Woodhead Publishing: Cambridge, UK, 2000; ISBN 9781855734258.

4. Yuksel, O.; Sandberg, M.; Baran, I.; Ersoy, N.; Hattel, J.H.; Akkerman, R. Material characterization of a pultrusion specific and highly reactive polyurethane resin system: Elastic modulus, rheology, and reaction kinetics. Compos. Part B Eng. 2020, 108543. [CrossRef]

5. Liu, T.; Feng, P.; Lu, X.; Yang, J.-Q.; Wu, Y. Flexural behavior of novel hybrid multicell GFRP-concrete beam. Compos. Struct. 2020, 250. [CrossRef]

6. Budiyantoro, C.; Rochardjo, H.S.B.; Nugroho, G. Effects of processing variables of extrusion-pultrusion method on the impregnation quality of thermoplastic composite filaments. Polymers 2020, 12, 2833. [CrossRef] 
7. Uslu, E.; Gavgali, M.; Erdal, M.O.; Yazman, S..; Gemi, L. Determination of mechanical properties of polymer matrix composites reinforced with electrospinning N66, PAN, PVA and PVC nanofibers: A comparative study. Mater. Today Commun. 2021, 26. [CrossRef]

8. Guo, Z.; Zhu, Y.; Chen, Y.; Zhao, Y. Test on residual ultimate strength of pultruded concrete-filled GFRP tubular short columns after lateral impact. Compos. Struct. 2020, 113520. [CrossRef]

9. Madenci, E.; Onuralp Özkılıç, Y.; Gemi, L. Buckling and free vibration analyses of pultruded GFRP laminated composites: Experimental, numerical and analytical investigations. Compos. Struct. 2020, 254. [CrossRef]

10. Ferdous, W.; Manalo, A.; AlAjarmeh, O.; Mohammed, A.A.; Salih, C.; Yu, P.; Mehrinejad Khotbehsara, M.; Schubel, P. Static behaviour of glass fibre reinforced novel composite sleepers for mainline railway track. Eng. Struct. 2021, 229. [CrossRef]

11. Li, C.; Xian, G. Mechanical property evolution and life prediction of carbon fiber and pultruded carbon fiber reinforced polymer plate exposed to elevated temperatures. Polym. Compos. 2020, 41, 5143-5155. [CrossRef]

12. Vedernikov, A.N.; Safonov, A.A.; Gusev, S.A.; Carlone, P.; Tucci, F.; Akhatov, I.S. Spring-in experimental evaluation of L-shaped pultruded profiles. IOP Conf. Ser. Mater. Sci. Eng. 2020, 747, 012013. [CrossRef]

13. Mukherji, A.; Njuguna, J. Shock Propagation Behaviour and Determination of Greisen State of Equation for Pultruded Polyester/Glass Fibre-Reinforced Composites. Compos. Struct. 2020, 113444. [CrossRef]

14. Sirajudeen, R.S.; Sekar, R. Buckling Analysis of Pultruded Glass Fiber Reinforced Polymer (GFRP) Angle Sections. Polymers 2020, 12, 2532. [CrossRef] [PubMed]

15. Ueda, M.; Ui, N.; Ohtani, A. Lightweight and anti-corrosive fiber reinforced thermoplastic rivet. Compos. Struct. 2018, 188, 356-362. [CrossRef]

16. Ding, L.; Liu, L.; Wang, X.; Shen, H.; Wu, Z. Effects of connecting materials on the static and fatigue behavior of pultruded basalt fiber-reinforced polymer bolted joints. Constr. Build. Mater. 2020, 121683. [CrossRef]

17. Haloi, J.; Kumar Mushahary, S.; Chandra Borsaikia, A.; Darunkumar Singh, K. Experimental investigation on the web crippling behaviour of pultruded GFRP wide-flange sections subjected to two-flange loading conditions. Compos. Struct. 2020, 113469. [CrossRef]

18. Wang, Z.; Li, C.; Sui, L.; Xian, G. Effects of adhesive property and thickness on the bond performance between carbon fiber reinforced polymer laminate and steel. Thin-Walled Struct. 2021, 158. [CrossRef]

19. Poulton, M.; Sebastian, W. Taxonomy of fibre mat misalignments in pultruded GFRP bridge decks. Compos. Part A Appl. Sci. Manuf. 2020, 106239. [CrossRef]

20. Borsellino, C.; Urso, S.; Alderucci, T.; Chiappini, G.; Rossi, M.; Munafò, P. Temperature effects on failure mode of double lap glass-aluminum and glass-GFRP joints with epoxy and acrylic adhesive. Int. J. Adhes. Adhes. 2021, 105. [CrossRef]

21. Kar, K.K. Composite Materials. Processing, Application, Characterization; Springer: Berlin/Heidelberg, Germany, 2017; ISBN 9783662495148.

22. Advani, S.G.; Hsiao, K.T. Introduction to composites and manufacturing processes. In Manufacturing Techniques for Polymer Matrix Composites (PMCs): A Volume in Woodhead Publishing Series in Composites Science and Engineering; Woodhead Publishing: Sawston, UK; Cambridge, UK, 2012.

23. Vedernikov, A.; Tucci, F.; Safonov, A.; Carlone, P.; Gusev, S.; Akhatov, I. Investigation on the Shape Distortions of Pultruded Profiles at Different Pulling Speed. Procedia Manuf. 2020, 47, 1-5. [CrossRef]

24. Sapanci, E.; Günay, G.E.; Aydoğmuş, A.; Roketsan, A.S. Composite canister profile manufacturing by pultrusion process. In Proceedings of the International SAMPE Technical Conference, Seattle, CA, USA, 22-26 May 2017.

25. Passos, A.; de Aguiar, R.; Costa, H.; Sampaio, E.; de Barros, S. Adherence of geopolymer and pultruded composite substrates: Influence of adhesive type and surface treatment. J. Adhes. Sci. Technol. 2020. [CrossRef]

26. Song, Y.S.; Youn, J.R.; Gutowski, T.G. Life cycle energy analysis of fiber-reinforced composites. Compos. Part A Appl. Sci. Manuf. 2009, 40, 1257-1265. [CrossRef]

27. Sandberg, M.; Yuksel, O.; Baran, I.; Hattel, J.H.; Spangenberg, J. Numerical and experimental analysis of resin-flow, heat-transfer, and cure in a resin-injection pultrusion process. Compos. Part A Appl. Sci. Manuf. 2020, 106231. [CrossRef]

28. Schäfer, J.; Gries, T.; Schuster, R.; Lammel, C. Continious production of fibre reinforced thermoplastic composites by braiding pultrusion. In Proceedings of the ICCM International Conferences on Composite Materials, Copenhagen, Denmark, 19-24 July 2015; Volume 2015.

29. Zou, X.; Lin, H.; Feng, P.; Bao, Y.; Wang, J. A review on FRP-concrete hybrid sections for bridge applications. Compos. Struct. 2020. [CrossRef]

30. Safonov, A.A.; Carlone, P.; Akhatov, I. Mathematical simulation of pultrusion processes: A review. Compos. Struct. 2018, 184, 153-177. [CrossRef]

31. Faruk, O.; Bledzki, A.K.; Fink, H.P.; Sain, M. Biocomposites reinforced with natural fibers: 2000-2010. Prog. Polym. Sci. 2012, 37, 1552-1596. [CrossRef]

32. Ma, C.C.M.; Yn, M.S. Poly ( $\epsilon$-caprolactam)-poly (butadiene-co-acrylonitrile) block copolymers II. Processability and properties of pultruded glass-fiber-reinforced composites. Mater. Chem. Phys. 1995, 42. [CrossRef]

33. Novo, P.J.; Silva, J.F.; Nunes, J.P.; Marques, A.T. Advances in thermoplastic pultruded composites. In Proceedings of the ICCM International Conferences on Composite Materials, Copenhagen, Denmark, 19 July 2015; Volume 2015. 
34. Pillay, S.; Thattaiparthasarathy, K.B.; Vaidya, U.K.; Husman, G. Development of pultrusion process and applications for thermoplastic composites. In Proceedings of the International SAMPE Symposium and Exhibition, Long Beach, CA, USA, 12-16 May 2007; Volume 52.

35. Sumerak, J.E. Pultruded composites in impact and toughness driven applications achieve new performance levels with polyurethane resin. In Proceedings of the International SAMPE Symposium and Exhibition, Long Beach, CA, USA, 11-15 May 2003; Volume 48 II.

36. Han, N.; Baran, I.; Zanjani, J.S.M.; Yuksel, O.; An, L.; Akkerman, R. Experimental and computational analysis of the polymerization overheating in thick glass/Elium ${ }^{\circledR}$ acrylic thermoplastic resin composites. Compos. Part B Eng. 2020, 202, 108430. [CrossRef]

37. Bechtold, G.; Wiedmer, S.; Friedrich, K. Pultrusion of thermoplastic composites-New developments and modelling studies. J. Thermoplast. Compos. Mater. 2002, 15. [CrossRef]

38. Miller, A.H.; Dodds, N.; Hale, J.M.; Gibson, A.G. High speed pultrusion of thermoplastic matrix composites. Compos. Part A Appl. Sci. Manuf. 1998, 29, 773-782. [CrossRef]

39. Vaughan, J.G.; Dillard, T.W.; Seal, E. A Characterization of the Important Parameters for Graphite/PEEK Pultrusion. J. Thermoplast. Compos. Mater. 1990, 3. [CrossRef]

40. Epple, S.; Bonten, C. Production of continuous fiber thermoplastic composites by in-situ pultrusion. AIP Conf. Proc. 2014, 1593, 454-457. [CrossRef]

41. Udipi, K.; Dave, R.S.; Kruse, R.L.; Stebbins, L.R. Anionic Polymerization of Lactams: Some Industrial Applications. ACS Symp. Ser. 1998, 696. [CrossRef]

42. Neise, E. Long-Fiber Reinforced Thermoplastics. Gummi Fasern Kunstst. 1986, 39, $282-287$.

43. Chauzu, F. Process for Producing a Rigid Composite Structure Obtained by welding Profiles and Rigid Frames Obtained Thereby. F.R. Patent 3037856A1, 29 June 2016.

44. Wei, S.M. Application study of FRTP materials in the civil engineering products. In Proceedings of the Applied Mechanics and Materials, Anshan, China, 13-17 July 2013; Volume 395-396.

45. Ben, G.; Hirabayashi, A.; Kawazoe, Y. Evaluation of quasi-isotropic plate and cylindrical shell fabricated with green composite sheets. Adv. Compos. Mater. 2013, 22. [CrossRef]

46. Lebel, L.L.; Nakai, A. Design and manufacturing of an L-shaped thermoplastic composite beam by braid-trusion. Compos. Part $A$ Appl. Sci. Manuf. 2012, 43, 1717-1729. [CrossRef]

47. Vincent, G.A.; de Bruijn, T.A.; Wijskamp, S.; van Drongelen, M.; Akkerman, R. Process- and material-induced heterogeneities in recycled thermoplastic composites. J. Thermoplast. Compos. Mater. 2020, 0892705720979347. [CrossRef]

48. Erber, A.; Janetzko, S.; Spitko, S.; Brudzinski, P.V. Comparison of process chains for the production of thermoplastic UD-tapes and organic sheets. In Proceedings of the ECCM 2016-Proceeding of the 17th European Conference on Composite Materials, Munich, Germany, 26-30 June 2016.

49. Edwards, C. Thermoplastic pultrusion promises new synergies. Reinf. Plast. 2001, 45. [CrossRef]

50. Ramani, K.; Borgaonkar, H.; Hoyle, C. Experiments on compression moulding and pultrusion of thermoplastic powder impregnated towpregs. Compos. Manuf. 1995, 6, 35-43. [CrossRef]

51. Liu, M.; Yan, B.; Peng, X.; Peng, F.; Wang, L. Crashworthiness of Thermoplastic Woven Glass Fabric Reinforced Composite Tubes Manufactured by Pultrusion. Fibers Polym. 2020, 21, 416-427. [CrossRef]

52. Suresh, S.; Senthil Kumar, V.S. Effects of fabric structure on the formability characteristics of thermoplastic composites under various process conditions. Trans. Can. Soc. Mech. Eng. 2018, 42, 298-308. [CrossRef]

53. Choudhury, M.R.; Debnath, K. A review of the research and advances in electromagnetic joining of fiber-reinforced thermoplastic composites. Polym. Eng. Sci. 2019, 59, 1965-1985. [CrossRef]

54. Ahmed, T.J.; Stavrov, D.; Bersee, H.E.N.; Beukers, A. Induction welding of thermoplastic composites-an overview. Compos. Part A Appl. Sci. Manuf. 2006, 37, 1638-1651. [CrossRef]

55. Bayerl, T.; Duhovic, M.; Mitschang, P.; Bhattacharyya, D. The heating of polymer composites by electromagnetic induction-A review. Compos. Part A Appl. Sci. Manuf. 2014, 57, 27-40. [CrossRef]

56. Kumar, R.; Singh, R.; Ahuja, I.P.S.; Penna, R.; Feo, L. Weldability of thermoplastic materials for friction stir welding- A state of art review and future applications. Compos. Part B Eng. 2018, 137, 1-15. [CrossRef]

57. Bhudolia, S.K.; Gohel, G.; Kantipudi, J.; Leong, K.F.; Barsotti, R.J. Ultrasonic welding of novel carbon/elium ${ }^{\circledR}$ thermoplastic composites with flat and integrated energy directors: Lap shear characterisation and fractographic investigation. Materials 2020, 13, 1634. [CrossRef]

58. Belingardi, G.; Beyene, A.T.; Koricho, E.G.; Martorana, B. Lightweight Solutions for Vehicle Frontal Bumper: Crash Design and Manufacturing Issues; Woodhead Publishing: Sawston, UK; Cambridge, UK, 2017; ISBN 9780081009024.

59. Guillon, D.; Lemasçon, A.; Callens, C. QSP ${ }^{\circledR}$ : An innovative process based on tailored preforms for low cost and fast production of optimized thermoplastic composite parts. In Proceedings of the ECCM 2016-Proceeding of the 17th European Conference on Composite Materials, Munich, Germany, 26-30 June 2016.

60. Flores, R.; Fuller, D.; Green, S.; Ho, T.; Kajdan, T.; Lee, R.; McKelvy, M.; Sutton, T.; Traugott, T. Long glass fiber polyolefin systems for automotive applications requiring UV and thermal stability. In Proceedings of the Society of Petroleum Engineers International Conference on Polyolefins 2006: From Reserves to Retailers-The Changes Confronting the Polyolefins Business Worldwide, Houston, TX, USA, 26 February-1 March 2006; Volume 2. 
61. Bartus, S.D.; Vaidya, U.K.; Ulven, C.A. Design and development of a long fiber thermoplastic bus seat. J. Thermoplast. Compos. Mater. 2006, 19. [CrossRef]

62. Mascarin, A.E.; Wzorek, J.F.; Rossi, G.; Brachos, V. Development of a manufacturing strategy for moderate volume production of a composite vehicle structure. In Proceedings of the SAE Technical Papers, Detroit, MI, USA, 29 September-1 October 1998.

63. Crosby, J.M.; Drye, T.R. Fracture Studies of Discontinuous Fiber Reinforced Thermoplastic Composites. J. Reinf. Plast. Compos. 1987, 6. [CrossRef]

64. Zoller, A.; Escalé, P.; Gérard, P. Pultrusion of Bendable Continuous Fibers Reinforced Composites with Reactive Acrylic Thermoplastic ELIUM®Resin. Front. Mater. 2019, 6, 1-9. [CrossRef]

65. Fortier, V.; Brunel, J.-E.; Lebel, L. Fastening composite structures using braided thermoplastic composite rivets. J. Compos. Mater. 2019, 54, 002199831986737. [CrossRef]

66. Offringa, A. Design and application of a pultrusion for multiple use in the Fokker 100. Compos. Struct. 1988, 10. [CrossRef]

67. Nunes, J.P.; Siva, J.F. Production of thermoplastic matrix towpregs for highly demanding and cost-effective commercial applications. In Proceedings of the Materials Science Forum, Guimaraes, Portugal, 18-22 April 2013; Volume 730-732.

68. Botelho, E.C.; Scherbakoff, N.; Rezende, M.C.; Kawamoto, A.M.; Sciamareli, J. Synthesis of polyamide 6/6 by interfacial polycondensation with the simultaneous impregnation of carbon fibers. Macromolecules 2001, 34. [CrossRef]

69. Taylor, S.R. Industrial/commercial applications for pultruded thermoplastic composites. In Proceedings of the International SAMPE Technical Conference, 24th and International SAMPE Metals and Metals Processing Conference, Toronto, ON, Canada, 20-24 October 1992; Volume 24.

70. Essiga, W.; Kreutzbruck, M. Development of an inline monitoring system for quality assurance of thermoplastic CFRP tape using air-coupled ultrasound. In Proceedings of the AIP Conference Proceedings, Cancun, Mexico, 10-14 December 2019; Volume 2139.

71. Yu, Z.; Wang, X.; Wu, D. Mechanical properties, impact fracture behavior, and morphology of long-polyimide-fiber-reinforced poly(butylene terephthalate) composites. J. Compos. Mater. 2017, 51. [CrossRef]

72. Peled, A.; Mobasher, B.; Cohen, Z. Mechanical properties of hybrid fabrics in pultruded cement composites. Cem. Concr. Compos. 2009, 31. [CrossRef]

73. Gilby, J. Pultrusion provides roof solution. Reinf. Plast. 1998, 42. [CrossRef]

74. Nunes, J.P.; Silva, J.F.; Ferreira, J.C.; Marques, A.T. New composite poles for electrical lighting, transport and distribution. In Proceedings of the ICCM International Conferences on Composite Materials, Edinburgh, Scotland, 27-31 July 2009.

75. Alam, P.; Ansell, M.P.; Smedley, D. Mechanical repair of timber beams fractured in flexure using bonded-in reinforcements. Compos. Part B Eng. 2009, 40, 95-106. [CrossRef]

76. Rubino, F.; Nisticò, A.; Tucci, F.; Carlone, P. Marine Application of Fiber Reinforced Composites: A Review. J. Mar. Sci. Eng. 2020, 8, 26. [CrossRef]

77. Summerscales, J. Composites manufacturing for marine structures. In Marine Applications of Advanced Fibre-Reinforced Composites; Woodhead Publishing: Sawston, UK; Cambridge, UK, 2016.

78. Seymour, R.J.; Sloan, F.E. Pultrusion and thermoforming of a graphite-reinforced-thermoplastic marine cable. In Proceedings of the International SAMPE Symposium and Exhibition (Proceedings), San Diego, CA, USA, 15-18 April 1991; Volume 36.

79. Chisholm, J.M.; Hahn, H.T.; Williams, J.G. Effect of seawater on the fracture toughness of pultruded rods. In Proceedings of the American Society of Mechanical Engineers, Applied Mechanics Division, AMD, Berkeley, CA, USA, 20-22 June 1988; Volume 92.

80. Buck, M. Advanced thermoplastic composites processing. JEC Compos. Mag. 2005, 14, 54-56.

81. Zhang, S.; Wang, X.; Wu, D. Design and fabrication of long-carbon-fiber-reinforced polyamide-6/nickel powder composites for electromagnetic interference shielding and high mechanical performance. Polym. Compos. 2016, 37, 2705-2718. [CrossRef]

82. Kemmerer, J.; Ward, S. Effects of fiber length and orientation on the electrical conductivity of long carbon fiber reinforced thermoplastic molding compounds. In Proceedings of the International SAMPE Symposium and Exhibition (Proceedings), Los Angeles, CA, USA, 20-22 June 1989; Volume 3.

83. Wood, K.; Skilton, R.W.; Wille, R.; Barré, T.; Hayes, J.; Harasin, S. High performance in the frame Waterborne finishes for PU pultrusion window profiles need no primer. Proc. Eur. Coat. J. 2013, 5, 18-22.

84. Nakai, A.; Uozumi, T.; Ohtani, A.; Kanamori, T.; Nagoh, S. High-cycle molding of continuous fiber reinforced thermoplastic composites pipe. In Proceedings of the ICCM International Conferences on Composite Materials, Copenhagen, Denmark, 19-24 July 2015; Volume 2015.

85. Cervenka, A. Composite pipes based on thermoplastic matrices reinforced by continuous fibres. In Proceedings of the Mechanics of Composite Materials and Structures, Troia, Portugal, 12-24 July 1999.

86. El-Tahan, M.; Galal, K.; Hoa, V.S. New thermoplastic CFRP bendable rebars for reinforcing structural concrete elements. Compos. Part B Eng. 2013, 45, 1207-1215. [CrossRef]

87. Montsinger, L.V. MTI thermoplastic pultrusion process. J. Eng. Appl. Sci. 1996, 2, 2546-2551.

88. Nakada, M.; Miyano, Y.; Morisawa, Y.; Nishida, H.; Hayashi, Y.; Uzawa, K. Prediction of statistical life time for unidirectional CFRTP under creep loading. J. Reinf. Plast. Compos. 2019, 38, 938-946. [CrossRef]

89. Greco, A.; Romano, G.; Maffezzoli, A. Selective reinforcement of LLDPE components produced by rotational molding with thermoplastic matrix pultruded profiles. Compos. Part B Eng. 2014, 56. [CrossRef] 
90. Wang, C.; Zhou, Z.; Zhang, Z.; Ou, J. Study on the fabricating process monitoring of thermoplastic based materials packaged OFBG and their sensing properties. In Proceedings of the Sensor Systems and Networks: Phenomena, Technology, and Applications for NDE and Health Monitoring, San Diego, CA, USA, 18-22 March 2007; Volume 6530.

91. Cowen, G.; Measuria, U.; Turner, R.M. Section pultrusions of continuous fibre reinforced thermoplastics. In Proceedings of the I Mech E Conference Publications (Institution of Mechanical Engineers), Liverpool, UK, 8-10 April 1986.

92. About Fiberline Building Profiles. Available online: https:/ fiberline.com/about-us/who-we-are/ (accessed on 18 December 2020).

93. Luisier, A.; Bourban, P.E.; Månson, J.A.E. Reaction injection pultrusion of PA12 composites: Process and modelling. Compos. Part A Appl. Sci. Manuf. 2003, 34, 583-595. [CrossRef]

94. Bechtold, G.; Wiedmer, S.; Friedrich, K. Composite Materials Pultrusion of Thermoplastic Composites-New Developments. J. Thermoplast. Compos. Mater. 2002, 15, 443-465. [CrossRef]

95. Carlsson, A.; Tomas Åström, B. Experimental investigation of pultrusion of glass fibre reinforced polypropylene composites. Compos. Part A Appl. Sci. Manuf. 1998, 29, 585-593. [CrossRef]

96. Carlsson, A.; Astrom, B.T. Modelling of heat transfer and crystallization kinetics in thermoplastic pultrusion. Int. SAMPE Symp. Exhib. 1996, 41, 1324-1334.

97. Bates, P.; Ekhator, I. Continuous consolidation of commingled glass and polypropylene roving. J. Reinf. Plast. Compos. 2004, 23, 1409-1424. [CrossRef]

98. Wiedmer, S.; Manolesos, M. An experimental study of the pultrusion of carbon fiber-polyamide 12 yarn. J. Thermoplast. Compos. Mater. 2006, 19, 97-112. [CrossRef]

99. Linganiso, L.Z.; Bezerra, R.; Bhat, S.; John, M.; Braeuning, R.; Anandjiwala, R.D. Pultrusion of flax/poly(lactic acid) commingled yarns and nonwoven fabrics. J. Thermoplast. Compos. Mater. 2014, 27, 1553-1572. [CrossRef]

100. Zhu A Thermoplastic-Composite-Material Pultrusion Technology. C.N. Patent 105599323A, 14 March 2016.

101. Hatano, D.; Takagi, M.; Ohtani, A.; Nakai, A. Pultrusion system for continuous fiber reinforced thermoplastic composite with braiding technique. In Proceedings of the 26th Annual Technical Conference of the American Society for Composites 2011 and the 2nd Joint US-Canada Conference on Composites, Jeju, Korea, 21-26 August 2011; Volume 2.

102. Takai, Y.; Nakai, A.; Hamada, H. Mechanical properties of thermoplastic pultrusion products with braiding technique. In Proceedings of the ICCM International Conferences on Composite Materials, Kyoto, Japan, 3-8 July 2007.

103. Reese, E. Thermoplastic FRP Multi-Chamber Hollow Profile and Wicket Pultrusion Process and Braided Pultrusion Plant for Its Production. D.E. Patent 102011119245A1, 22 November 2011.

104. Reese, E. Pultrusion Process for Producing a Thermoplastic FRP Hollow Profile. D.E. Patent 102016008192A1, 5 July 2016.

105. Reese, E. Braiding Pultrusion Method for Manufacturing Thermoplastic Fiber Reinforced Plastics Hollow Profile in Pultrusion System, Involves Creating Multi-Layered Hollow Profile Braid of Multiple Hybrid Rovings Fiber Tapes. D.E. Patent 102011018420A1, 21 March 2011.

106. Reese, E. Continuous Braiding Pultrusion Process for a Thermoplastic FRP Hollow Section and Braided Pultrusion Line. D.E. Patent 102011018422A1, 21 April 2011.

107. Reese, E. Braid Pultrusion Method for Manufacturing Bent Thermoplastic or Fiber Reinforced Plastic-Hollow in Pultrusion System, Involves Generating Multi-Layer Hollow Profile Braid Made of Multiple Hybrid Rovings or Fiber Tapes. D.E. Patent 102011100546A1, 5 May 2011.

108. Memon, A.; Nakai, A. Mechanical properties of jute spun Yarn/PLA tubular braided composite by pultrusion molding. Energy Procedia 2013, 34, 818-829. [CrossRef]

109. Guan, Y.; Qu, X.; Shi, Y.; Qu, C. Fiber Reinforced Thermoplastic Composite Material Direct Online Pultrusion Moulding Device. C.N. Patent 102363363B, 25 October 2011.

110. Cheng, Y.; Cheng, Z. Pultrusion Method and Equipment for Thermoplastic Composite Material of Continuous Fiber. C.N. Patent 101913255A, 13 September 2010.

111. Kilian, B.; Bruening, D.; Remmel, J. Pultrusion Method for Producing Fibre-Reinforced Plastic Profiled Sections and Pultrusion Device. U.S. Patent 20200282674A1, 6 October 2017.

112. Louis, L.L.; Mannot, P.; Oswald, A.; Lapointe, F. Pultruded Beam Reinforced With Natural Fibers, Pultrusion System and Method Therefor. U.S. Patent 20190193346A1, 22 June 2017.

113. Johnson, D.W.; Garrett, S.A.; Moyers, S.G. Thermoplastic Pultrusion Die System and Method. U.S. Patent 8684722B1, 24 March 2009.

114. Johnson, D.W.; Garrett, S.A.; Moyers, S.G. Thermoplastic Pultrusion die System and Method. U.S. Patent 8747098B1, 9 October 2013.

115. Montsinger, L.V. Apparatus and Method for Forming Fiber Filled Thermoplastic Composite Materials. U.S. Patent 5176775A, 16 December 1991.

116. Pilling, D.A.; Korzeniowski, G. Method for Pultruding Fiber-Reinforced, Thermoplastic Stock. U.S. Patent 5114516A, 5 October 1990.

117. Pfeiffer, B.; Skaletz, D.; Heckel, H.; Texier, A.; Heydweiller, J. Production of Fiber-Reinforced Composites by Pultrusion with Thermoplastic Powder Pretreatment. U.S. Patent 5725710A, 28 July 1993.

118. Ehleben, M.; Mertens, T.; Briesemann, S.; Fleischhauer, M. Process for Producing a Pultruded Fiber Composite Plastic Profile. D.E. Patent 102016206025A1, 12 April 2016.

119. Hilakos, W.; Patterson, D.J. Pultrusion Apparatus and Method for Impregnating Continuous Lengths of Multi-Filament and Multi-fiber Structures. U.S. Patent 4907527A, 15 December 1987. 
120. James, E.; O'Connor Beever, W.H.; Dancer, J.W.; Beaulieu, W.B.; Selby, L.M.; Virgil, H.; Rhodes, J. Pultrusion Process and Apparatus. U.S. Patent 4883552A, 5 December 1986.

121. Lambing, C.L.T.; Barbus, J.J.; Miller, D.C. Method for Pultruding Fiber-Reinforced Thermoplastic stock. U.S. Patent 5264060A, 22 January 1992.

122. Hornung, S.; Weicker, S. Process for Producing a Fiber-Reinforced Plastic Profile and a Fiber-Reinforced Plastic Profile. D.E. Patent 102017219715A1, 7 November 2017.

123. Taylor, S.R. Apparatus for Pultruding Thermoplastic Structures at Below Melt Temperatures. U.S. Patent 5091036A, 5 October 1989.

124. Beever, W.H. Thermoplastic Re-Pultrusion. U.S. Patent 4992229A, 14 February 1991.

125. O'Connor, J.E. Method for Making Variable Cross Section Pultruded Thermoplastic Composite Articles. U.S. Patent 5026447A, 10 February 1991.

126. Chauzu, F. Method and Installation for Obtaining a Profile of a Section Variated by Pultrusion. F.R. Patent 3053915B1, 18 July 2019.

127. Zhou, X.; Fang, L.; Guo, B.; Huang, S.; Lin, Q.; Fan, C. Production Equipment and Using Method for Thermoplastic Pultrusion Product. C.N. Patent 102615840A, 9 April 2012.

128. Beever, W.H. Method and Apparatus for Pultruding Non-Linear Thermoplastic Composite articles. U.S. Patent 4892600A, 15 December 1990.

129. Edwards, C.M.; D’Hooghe, E.L. Process for In-Line Forming of Pultruded Composites. U.S. Patent 6872343B2, 13 January 2005.

130. Rubin, A.; Fox, J.; Wilkerson, R. Fabrication Process for Thermoplastic Composite Parts. U.S. Patent 8795457B2, 2 February 2014.

131. Ishida, H.; Zimmerman, D.A. The development of an epoxy resin system for the injection molding of long-fiber epoxy composties. Polym. Compos. 1994, 15. [CrossRef]

132. Ageyeva, T.; Sibikin, I.; Karger-Kocsis, J. Polymers and related composites via anionic ring-opening polymerization of lactams: Recent developments and future trends. Polymers 2018, 10, 357. [CrossRef]

133. Botelho, E.C.; Rezende, M.C. Reaction injection pultrusion: A potential technique to process polyamide 6,6/carbon fiber composites. J. Adv. Mater. 2004, 36, 49-53.

134. Ning, X.; Ishida, H. RIM-pultrusion of nylon-6 and rubber-toughened nylon-6 composites. Polym. Eng. Sci. 1991, 31. [CrossRef]

135. Ishida, H.; Rotter, G. RIM-pultrusion of thermoplastic matrix composites. In Proceedings of the Society of the Plastics Industry, Reinforced Plastics/Composites Institute, Annual Conference-Proceedings, Cincinnati, OH, USA, 1-5 February 1988.

136. Chauzu, F. Method for Obtaining a Profiled Part Made of Thermoplastic Composite Material, and Device for Carrying out Said Method. E.P. Patent 3272506A1, 18 July 2016.

137. Chen, J.H.; Kang, H.C.; Kang, C.J.; Wu, Y.D.; Laiw, R.F. Pultrusion Process for Long Fiber-Reinforced Nylon Composites. U.S. Patent 5424388A, 24 June 1993.

138. Ageyeva, T.; Sibikin, I.; Kovács, J.G. Review of thermoplastic resin transfer molding: Process modeling and simulation. Polymers 2019, 11, 1555. [CrossRef]

139. Cho, B.G.; Mccarthy, S.P.; Fanucci, J.P.; Nolet, S.C. Fiber reinforced nylon-6 composites produced by the reaction injection pultrusion process. Polym. Compos. 1996, 17, 673-681. [CrossRef]

140. Van Rijswijk, K.; Bersee, H.E.N.; Jager, W.F.; Picken, S.J. Optimisation of anionic polyamide-6 for vacuum infusion of thermoplastic composites: Choice of activator and initiator. Compos. Part A Appl. Sci. Manuf. 2006, 37, 949-956. [CrossRef]

141. Chen, K.; Jia, M.; Hua, S.; Xue, P. Optimization of initiator and activator for reactive thermoplastic pultrusion. J. Polym. Res. 2019, 26. [CrossRef]

142. Yn, M.S.; Ma, C.C.M.; Lin, S.H.; Wu, Y.D. Pultrusion of poly( $\varepsilon$-caprolactam)/poly(butadiene-co-acrylonitrile) composites: I. Simulation and a mathematical model. Compos. Sci. Technol. 1995, 54, 123-131. [CrossRef]

143. Åström, B.T.; Larsson, P.H.; Hepola, P.J.; Pipes, R.B. Flexural properties of pultruded carbon/PEEK composites as a function of processing history. Composites 1994, 25, 814-821. [CrossRef]

144. Kerbiriou, V.; Friedrich, K. Pultrusion of Thermoplastic Composites-Process Optimization and Mathematical Modeling. J. Thermoplast. Compos. Mater. 1999, 12, 96-120. [CrossRef]

145. Bechtold, G.; Sakaguchi, M.; Friedrich, K.; Hamada, H. Pultrusion of micro-braided GF/PA6 yarn. Adv. Compos. Lett. 1999, 8. [CrossRef]

146. Evstatiev, M.; Angelov, I.; Friedrich, K. Structure and properties of microfibrillar-reinforced composites based on thermoplastic PET/LDPE blends after manufacturing by means of pultrusion. Polym. Eng. Sci. 2010, 50. [CrossRef]

147. Michaeli, W.; Jürss, D. Thermoplastic pull-braiding: Pultrusion of profiles with braided fibre lay-up and thermoplastic matrix system (PP). Compos. Part A Appl. Sci. Manuf. 1996, 27, 3-7. [CrossRef]

148. Nejhad, M.N.G. Thermal Analysis for Thermoplastic Composite Tow/Tape Preheating and Pultrusion. J. Thermoplast. Compos. Mater. 1997, 10, 504-523. [CrossRef]

149. Lapointe, F.; Laberge Lebel, L. Fiber damage and impregnation during multi-die vacuum assisted pultrusion of carbon/PEEK hybrid yarns. Polym. Compos. 2019, 40, E1015-E1028. [CrossRef]

150. Schäfer, J.; Gries, T. Alternative heating technology for the braiding pultrusion process. In Proceedings of the CAMX 2016Composites and Advanced Materials Expo, Anaheim, CA, USA, 26-29 September 2016.

151. Oswald, A.; Lapointe, F.L.; Laberge Lebel, L. Multi-die, vacuum assisted pultrusion of flax/PLA thermoplastic biocomposite rods. In Proceedings of the ECCM 2016-Proceeding of the 17th European Conference on Composite Materials, Munich, Germany, 26-30 June 2016. 
152. Wongsriraksa, P.; Nakai, A. A study on the processing ability of carbon fiber reinforced thermoplastic epoxy resin composites by using pultrusion technique. In Proceedings of the ICCM International Conferences on Composite Materials, Xi'an, China, 20-25 August 2017; Volume 2017.

153. Wongsriraksa, P.; Nakai, A. The Effect of Process Parameters on Impregnation Properties of Pultruded Carbon Fiber Reinforced Thermoplastic Epoxy Composites. ECS Trans. 2018, 88, 177-185. [CrossRef]

154. Chen, K.; Jia, M.; Sun, H.; Xue, P. Thermoplastic reaction injection pultrusion for continuous glass fiber-reinforced polyamide-6 composites. Materials 2019, 12, 463. [CrossRef]

155. Åström, B.T. Development and application of a process model for thermoplastic pultrusion. Compos. Manuf. 1992, 3, $189-197$. [CrossRef]

156. Glemet, M.; Causier, A.; Gourdon, B. Pultrusion Process. U.S. Patent 5084222A, 18 Febuary 1987.

157. Hepola, P.J. Thermoplastic Pultrusion with On-Line Dry Powder Impregnation of Fibers. Ph.D. Thesis, University of Delaware, Newark, DE, USA, 1993.

158. Tomas åström, B.; Larsson, P.H.; Byron Pipes, R. Development of a facility for pultrusion of thermoplastic-matrix composites. Compos. Manuf. 1991, 2. [CrossRef]

159. Fanucci, J.P.; Nolet, S.C.; Koppernaes, C.; Kim, Y.R. Measurement of internal die pressure distributions during pultrusion of thermoplastic composites. Sampe 1990, 22, 50-64.

160. Michaeli, W.; Blaurock, J. Pultrusion of endless fibre-reinforced profiles with thermoplastic matrix systems. Eng. Plast. 1996, 9 , 282-292.

161. Ghaedsharaf, M.; Brunel, J.-E.; Lebel, L. Thermoplastic composite rod manufacturing using biaxial braid-trusion. In Proceedings of the ECCM18-18th European Conference on Composite Materials, Athens, Greece, 24-28 June 2018.

162. Devlin, B.J.; Williams, M.D.; Quinn, J.A.; Gibson, A.G. Pultrusion of unidirectional composites with thermoplastic matrices. Compos. Manuf. 1991, 2, 203-207. [CrossRef]

163. Sala, G.; Cutolo, D. The pultrusion of powder-impregnated thermoplastic composites. Compos. Part A Appl. Sci. Manuf. 1997, 28, 637-646. [CrossRef]

164. Astroem, B.T.; Larsson, P.H.; Pipes, R.B. Experimental investigation of a thermoplastic pultrusion process. In Proceedings of the International SAMPE Symposium and Exhibition (Proceedings), San Diego, CA, USA, 15-18 April 1991; Volume 36.

165. Squires, C.; Almaraz, J.; O'Toole, B. Experimental simulation of the thermoplastic pultrusion process. Int. SAMPE Symp. Exhib. 1996, 41 .

166. Azari, A.D. Influence of the pultrusion line speed on the mechanical properties of the thermoplastic rovings impregnated long fiber. J. Eng. Appl. Sci. 1996, 2, 2526-2530.

167. Ozturk, O.; Das, P.; Stadler, M.; Pipes, R.B. Optimization of thermoplastic impregnation of glass fiber yarns with pultrusion. In Proceedings of the Annual Technical Conference-ANTEC, Conference Proceedings, Chicago, IL, USA, 16-20 May 2004; Volume 2.

168. Nunes, J.P.; Silva, J.F.; Novo, P.J. Processing thermoplastic matrix towpregs by pultrusion. Adv. Polym. Technol. 2013, 32. [CrossRef]

169. Åstroöm, B.T.; Pipes, R.B. A modeling approach to thermoplastic pultrusion. II: Verification of models. Polym. Compos. 1993, 14, 184-194. [CrossRef]

170. Nakai, A.; Morino, K. Molding condition for shortening molding time during pultrusion molding of thermoplastic composites. In Proceedings of the ICCM International Conferences on Composite Materials, Xi'an, China, 20-25 August 2017 ; Volume 2017.

171. Vedernikov, A.; Tucci, F.; Carlone, P.; Gusev, S.; Konev, S.; Firsov, D.; Akhatov, I.; Safonov, A. Effects of pulling speed on structural performance of L-shaped pultruded profiles. Compos. Struct. 2021, 255. [CrossRef]

172. Svensson, N.; Shishoo, R.; Gilchrist, M. Manufacturing of thermoplastic composites from commingled yarns-A review. J. Thermoplast. Compos. Mater. 1998, 11, 22-56. [CrossRef]

173. Longmuir, A.; Wilcox, J. Bridging the gap between pultrusions and extrusions. Mater. World 2000, 8, 18-20.

174. Thomasset, J.; Carreau, P.J.; Sanschagrin, B.; Ausias, G. Rheological properties of long glass fiber filled polypropylene. J. Nonnewton. Fluid Mech. 2005, 125. [CrossRef]

175. Broyles, N.S.; Verghese, K.N.E.; Davis, R.M.; Lesko, J.J.; Riffle, J.S. Pultruded carbon fiber/vinyl ester composites processed with different fiber sizing agents. Part I: Processing and static mechanical performance. J. Mater. Civ. Eng. 2005, 17, 320-333. [CrossRef]

176. Verghese, K.N.; Broyles, N.S.; Lesko, J.J.; Davis, R.M.; Riffle, J.S. Pultruded Carbon Fiber/Vinyl Ester Composites Processed with Different Fiber Sizing Agents. Part II: Enviro-Mechanical Durability. J. Mater. Civ. Eng. 2005, 17. [CrossRef]

177. Verghese, K.N.; Broyles, N.S.; Case, S.W.; Lesko, J.J.; Davis, R.M.; Riffle, J.S. Pultruded Carbon Fiber/Vinyl Ester Composites Processed with Different Fiber Sizing Agents. Part III: Theoretical Aspects. J. Mater. Civ. Eng. 2005, 17. [CrossRef]

178. Roy, S.; Lu, H.; Narasimhan, K.; Hussain, F. Characterization and modeling of strength enhancement mechanisms in a polymer/clay nanocomposite. In Proceedings of the Collection of Technical Papers-AIAA/ASME/ASCE/AHS/ASC Structures, Structural Dynamics and Materials Conference, Austin, TX, USA, 18-21 April 2005; Volume 1.

179. Roy, S.; Vengadassalam, K.; Hussain, F.; Lu, H. Compressive strength enhancement of pultruded thermoplastic composites using nanoclay reinforcement. In Proceedings of the International SAMPE Symposium and Exhibition (Proceedings), Long Beach, CA, USA, 16-20 May 2004; Volume 49. 
180. Fink, H.P.; Ganster, J. Novel thermoplastic composites from commodity polymers and man-made cellulose fibers. In Proceedings of the Macromolecular Symposia, Rio de Janeiro, Brazil, 16-21 July 2006; John Wiley \& Sons Ltd.: Chichester, UK, 2006; Volume 244.

181. Novo, P.J.; Silva, J.F.; Nunes, J.P.; Van Hattum, F.W.J.; Marques, A.T. Development of a new pultrusion equipment to manufacture thermoplastic matrix composite profiles. In Proceedings of the ECCM 2012-Composites at Venice, Proceedings of the 15th European Conference on Composite Materials; European Conference on Composite Materials, ECCM, Venice, Italy, 24-28 June 2012.

182. Tao, Z.; Wang, Y.; Li, J.; Wang, X.; Wu, D. Fabrication of long glass fiber reinforced polyacetal composites: Mechanical performance, microstructures, and isothermal crystallization kinetics. Polym. Compos. 2015, 36. [CrossRef]

183. Wang, Y.; Wang, X.; Wu, D. Mechanical and tribological enhancement of polyoxymethylene-based composites with long basalt fiber through melt pultrusion. Compos. Interfaces 2016, 23. [CrossRef]

184. Kahl, C.; Feldmann, M.; Heim, H.P. Inline UV light irradiation of cellulose and glass fibers in pultrusion of thermoplastic composites. In Proceedings of the Annual Technical Conference-ANTEC, Conference Proceedings, Orlando, FL, USA, 7-10 May 2018; Volume 2018.

185. Shayan Asenjan, M.; Sabet, A.R.; Nekoomanesh, M. Long fiber thermoplastic composites under high-velocity impact: Study of fiber length. J. Compos. Mater. 2019, 53, 353-360. [CrossRef]

186. Saito, T.; Nakai, A.; Ohtani, A. Effects of fabrication method of composite yarn intermediate material and resin melt viscosity on the impregnation properties and mechanical properties of PA66 fiber and glass fiber composites. J. Thermoplast. Compos. Mater. 2020. [CrossRef]

187. Asensio, M.; Esfandiari, P.; Núñez, K.; Silva, J.F.; Marques, A.; Merino, J.C.; Pastor, J.M. Processing of pre-impregnated thermoplastic towpreg reinforced by continuous glass fibre and recycled PET by pultrusion. Compos. Part B Eng. 2020, 200, 108365. [CrossRef]

188. Vaidya, U.K.; Chawla, K.K. Processing of fibre reinforced thermoplastic composites. Int. Mater. Rev. 2008, 53, 185-218. [CrossRef]

189. Van De Velde, K.; Kiekens, P. Thermoplastic pultrusion of natural fibre reinforced composites. Compos. Struct. 2001, 54, 355-360. [CrossRef]

190. Tan, Y.; Wang, X.; Wu, D. Preparation, microstructures, and properties of long-glass-fiber-reinforced thermoplastic composites based on polycarbonate/poly(butylene terephthalate) alloys. J. Reinf. Plast. Compos. 2015, 34, 1804-1820. [CrossRef]

191. Wypych, G. Handbook of Polymers; ChemTec Publishing: Ontario, ON, Canada, 2012.

192. Novo, P.J.; Silva, J.F.; Nunes, J.P.; Marques, A.T. Pultrusion of fibre reinforced thermoplastic pre-impregnated materials. Compos. Part B Eng. 2016. [CrossRef]

193. Wilson, M.L.; Buckley, J.D. The Potential for Low Cost Thermoplastic Pultrusion. J. Reinf. Plast. Compos. 1994, $13,927-941$. [CrossRef]

194. Nunes, J.P.; Van Hattum, F.W.J.; Bernardo, C.A.; Silva, J.F.; Marques, A.T. Advances in thermoplastic matrix towpregs processing. J. Thermoplast. Compos. Mater. 2004, 17, 523-544. [CrossRef]

195. Chan, C.M.; Vandi, L.J.; Pratt, S.; Halley, P.; Richardson, D.; Werker, A.; Laycock, B. Composites of Wood and Biodegradable Thermoplastics: A Review. Polym. Rev. 2018, 58, 444-494. [CrossRef]

196. Wilson, M.L.; Buckley, J.D.; Dickerson, G.E.; Johnson, G.S.; Taylor, E.C.; Covington, E.W. Pultrusion Process Development of a Graphite Reinforced Polyetherimide Thermoplastic Composite. J. Thermoplast. Compos. Mater. 1989, 2, 230-246. [CrossRef]

197. Larock, J.A.; Hahn, H.T.; Evans, D.J. Pultrusion Processes for Thermoplastic Composites. J. Thermoplast. Compos. Mater. 1989. [CrossRef]

198. Hedayati Velis, H.; Golzar, M.; Yousefzade, O. Composites based on HDPE, jute fiber, wood, and thermoplastic starch in tubular pultrusion die: The correlation between mechanical performance and microstructure. Adv. Polym. Technol. 2018, 37, 3483-3491. [CrossRef]

199. Ma, C.C.M.; Yn, M.S.; Chen, C.H.; Chiang, C.L. Processing and properties of pultruded thermoplastic composites (I). Compos. Manuf. 1990, 1, 191-196. [CrossRef]

200. Kumar, A.; Srivastava, A. Preparation and Mechanical Properties of Jute Fiber Reinforced Epoxy Composites. Ind. Eng. Manag. 2017, 6, 4-7. [CrossRef]

201. Qian, H.; Greenhalgh, E.S.; Shaffer, M.S.P.; Bismarck, A. Carbon nanotube-based hierarchical composites: A review. J. Mater. Chem. 2010, 20, 4751-4762. [CrossRef]

202. Sattar, R.; Kausar, A.; Siddiq, M. Advances in thermoplastic polyurethane composites reinforced with carbon nanotubes and carbon nanofibers: A review. J. Plast. Film Sheeting 2015, 31, 186-224. [CrossRef]

203. Markov, A.V. The effect of the manufacturing procedure on the electric properties of carbon-black-filled, fiberglass-reinforced thermoplastic composites. Polym. Sci. Ser. A 2007, 49. [CrossRef]

204. Novo, P.J.; Nunes, J.P.; Silva, J.F.; Tinoco, V.; Marques, A.T. Production of thermoplastics matrix preimpregnated materials to manufacture composite pultruded profiles. Cienc. Tecnol. Mater. 2013, 25, 85-91. [CrossRef]

205. Iftekhar, M.A. Effect of processing and material modifications on the viscosity of engineering thermoplastics at high temperatures. In Proceedings of the Annual Technical Conference-ANTEC, Conference Proceedings, Toronto, ON, Canada, 27 April-2 May 1997; Volume 2. 
206. Mariatti, M.; Nasir, M.; Ismail, H. Effect of prepreg geometry on the prepreg and plain weave composite properties. J. Reinf. Plast. Compos. 2002, 21. [CrossRef]

207. Zhou, H. Production Technology of Continuous Fiber Reinforced Thermoplastic Composites (CFRTP) Pultruded Profiles. C.N. Patent 106626444A, 27 July 2016.

208. Eastep, D.W.; Wesley, M.L.; Heydweiller, J.; Stiehm, R.; Littwitz, B.; Borgner, T.; Wagner, B.; Bernd, H. Method of Making Long Fiber-Reinforced Thermoplastic Composites Utilizing Hybrid or Commingled Yarn. W.O. Patent 2004080698A1, 6 March 2004.

209. Ye, L.; Friedrich, K.; Kästel, J. Consolidation of GF/PP commingled yarn composites. Appl. Compos. Mater. 1994, 1, 415-429. [CrossRef]

210. Van West, B.P.; Pipes, R.B.; Advani, S.G. The consolidation of commingled thermoplastic fabrics. Polym. Compos. 1991, $12,417-427$. [CrossRef]

211. Klinkmüller, V.; Um, M.K.; Steffens, M.; Friedrich, K.; Kim, B.S. A new model for impregnation mechanisms in different GF/PP commingled yarns. Appl. Compos. Mater. 1994, 1, 351-371. [CrossRef]

212. Kim, D.H.; Lee, W.I.; Friedrich, K. A model for a thermoplastic pultrusion process using commingled yarns. Compos. Sci. Technol. 2001, 61, 1065-1077. [CrossRef]

213. Bernet, N.; Michaud, V.; Bourban, P.E.; Manson, J.A.E. Impregnation model for the consolidation of thermoplastic composites made from commingled yarns. J. Compos. Mater. 1999, 33, 751-772. [CrossRef]

214. Mota, J.N.F.DA.; Nunes, J.P.L.G.; Pouzada, A.S.D. Pultrusion Head to Produce Long Fibre Reinforced Thermoplastic Matrix Profiles. W.O. Patent 2002006037A1, 14 July 2000.

215. Novo, P.J.; Silva, J.F.; Nunes, J.P.; Marques, A.T. Optimizing the production and processing of fibre reinforced thermoplastic pre-impregnated materials. In Proceedings of the 16th European Conference on Composite Materials, ECCM, Seville, Spain, 22-26 June 2014.

216. ASTM Standard ASTM D6641/D6641M-16e1. Standard Test Method for Compressive Properties of Polymer Matrix Composite Materials Using a Combined Loading Compression (CLC) Test Fixture; ASTM International: West Conshohocken, PA, USA, 2016.

217. EN ISO 527-5:2009. Plastics-Determination of Tensile Properties—Part 5: Test Conditions for Unidirectional Fibre-Reinforced Plastic Composites. Available online: https:/ / www.iso.org/standard/52991.html (accessed on 21 December 2020).

218. ASTM D790-03. Standard Test Methods for Flexural Properties of Unreinforced and Reinforced Plastics and Electrical Insulating Materials; ASTM International: West Conshohocken, PA, USA, 2003.

219. ASTM D7078/D7078M-12. Standard Test Method for Shear Properties of Composite Materials by V-Notched Rail Shear Method; ASTM International: West Conshohocken, PA, USA, 2019.

220. ASTM D2344/D2344M-16. Standard Test Method for Short-Beam Strength of Polymer Matrix Composite Materials and Their Laminates; ASTM International: West Conshohocken, PA, USA, 2016.

221. Ma, C.-C.M.; Chen, C. Pultruded fiber-reinforced poly(methyl methacrylate) composites. I. Effect of processing parameters on mechanical properties. J. Appl. Polym. Sci. 1992, 44, 807-817. [CrossRef]

222. Dubé, M.G.; Batch, G.L.; Vogel, J.G.; Macosko, C.W. Reaction injection pultrusion of thermoplastic and thermoset composites. Polym. Compos. 1995, 16, 378-385. [CrossRef]

223. Sousa, J.M.; Garrido, M.; Correia, J.R.; Cabral-Fonseca, S. Hygrothermal ageing of pultruded GFRP profiles: Comparative study of unsaturated polyester and vinyl ester resin matrices. Compos. Part A Appl. Sci. Manuf. 2021, 140. [CrossRef]

224. Spaccini, R.; Todisco, D.; Drosos, M.; Nebbioso, A.; Piccolo, A. Decomposition of bio-degradable plastic polymer in a real on-farm composting process. Chem. Biol. Technol. Agric. 2016, 3, 1-12. [CrossRef]

225. Madhavan Nampoothiri, K.; Nair, N.R.; John, R.P. An overview of the recent developments in polylactide (PLA) research. Bioresour. Technol. 2010, 101, 8493-8501. [CrossRef]

226. Leja, K.; Lewandowicz, G. Polymer biodegradation and biodegradable polymers-A review. Polish J. Environ. Stud. 2010, 19, 255-266.

227. Van de Velde, K.; Kiekens, P. Biopolymers: Overview of several properties and consequences on their applications. Polym. Test. 2001, 99, 483. [CrossRef]

228. Zobel, D.A. A New Class of Biodegradable Materials: Poly-3-hydroxy- butyrate/ Steam Exploded Straw Fiber Composites. 1. Thermal and Impact Behaviour. J. Appl. Polym. Sci. 1993, 88, 116. [CrossRef]

229. Ishiaku, U.S.; Pang, K.W.; Lee, W.S.; Ishak, Z.A.M. Mechanical properties and enzymic degradation of thermoplastic and granular sago starch filled poly( $\varepsilon$-caprolactone). Eur. Polym. J. 2002, 38, 393-401. [CrossRef]

230. Ratto, J.A.; Stenhouse, P.J.; Auerbach, M.; Mitchell, J.; Farrell, R. Processing, performance and biodegradability of a thermoplastic aliphatic polyester/starch system. Polymer 1999, 40, 6777-6788. [CrossRef]

231. Sinha Ray, S.; Okamoto, M. Biodegradable polylactide and its nanocomposites: Opening a new dimension for plastics and composites. Macromol. Rapid Commun. 2003, 24, 815-840. [CrossRef]

232. Leonor, I.B.; Ito, A.; Onuma, K.; Kanzaki, N.; Reis, R.L. In vitro bioactivity of starch thermoplastic/hydroxyapatite composite biomaterials: An in situ study using atomic force microscopy. Biomaterials 2003, 24, 579-585. [CrossRef]

233. Shogren, R.L.; Doane, W.M.; Garlotta, D.; Lawton, J.W.; Willett, J.L. Biodegradation of starch/polylactic acid/poly(hydroxyesterether) composite bars in soil. Polym. Degrad. Stab. 2003, 79, 405-411. [CrossRef]

234. Iovino, R.; Zullo, R.; Rao, M.A.; Cassar, L.; Gianfreda, L. Biodegradation of poly(lactic acid)/starch/coir biocomposites under controlled composting conditions. Polym. Degrad. Stab. 2008, 93, 147-157. [CrossRef] 
235. Strömberg, E.; Karlsson, S. The effect of biodegradation on surface and bulk property changes of polypropylene, recycled polypropylene and polylactide biocomposites. Int. Biodeterior. Biodegrad. 2009, 63, 1045-1053. [CrossRef]

236. Nourbakhsh, A.; Ashori, A.; Kazemi Tabrizi, A. Characterization and biodegradability of polypropylene composites using agricultural residues and waste fish. Compos. Part B Eng. 2014, 56, 279-283. [CrossRef]

237. Akonda, M.; Alimuzzaman, S.; Shah, D.U.; Rahman, A.N.M.M. Physico-mechanical, thermal and biodegradation performance of random flax/polylactic acid and unidirectional flax/polylactic acid biocomposites. Fibers 2018, 6, 98. [CrossRef]

238. Ashori, A. Wood-plastic composites as promising green-composites for automotive industries! Bioresour. Technol. 2008, 99, 4661-4667. [CrossRef] [PubMed]

239. Timar, M.C.; Pitman, A.; Mihai, M.D. Biological resistance of chemically modified aspen composites. Int. Biodeterior. Biodegrad. 1999, 43, 181-187. [CrossRef]

240. Zhang, M.Q.; Rong, M.Z.; Lu, X. Fully biodegradable natural fiber composites from renewable resources: All-plant fiber composites. Compos. Sci. Technol. 2005, 65, 2514-2525. [CrossRef]

241. Mohanty, A.K.; Wibowo, A.; Misra, M.; Drzal, L.T. Development of Renewable Resource-Based Cellulose Acetate Bioplastic: Effect of Process Engineering on the Performance of Cellulosic Plastics. Polym. Eng. Sci. 2003, 43, 1151-1161. [CrossRef]

242. Mishra, S.; Mohanty, A.K.; Drzal, L.T.; Misra, M.; Hinrichsen, G. A review on pineapple leaf fibers, sisal fibers and their biocomposites. Macromol. Mater. Eng. 2004, 289, 955-974. [CrossRef]

243. Corbière-Nicollier, T.; Gfeller Laban, B.; Lundquist, L.; Leterrier, Y.; Månson, J.A.E.; Jolliet, O. Life cycle assessment of biofibres replacing glass fibres as reinforcement in plastics. Resour. Conserv. Recycl. 2001, 33, 267-287. [CrossRef]

244. Wang, X.; Zhao, X.; Chen, S.; Wu, Z. Static and fatigue behavior of basalt fiber-reinforced thermoplastic epoxy composites. J. Compos. Mater. 2020, 54, 2389-2398. [CrossRef]

245. Nikforooz, M.; Montesano, J.; Golzar, M.; Shokrieh, M.M. Assessment of failure toughening mechanisms in continuous glass fiber thermoplastic laminates subjected to cyclic loading. Compos. Part B Eng. 2019, 161, 344-356. [CrossRef]

246. Ahlborn, K. Durability of carbon fibre reinforced plastics with thermoplastic matrices under cyclic mechanical and cyclic thermal loads at cryogenic temperatures. Cryogenics 1991, 31, 257-260. [CrossRef]

247. D'Amore, A.; Caprino, G.; Nicolais, L.; Marino, G. Long-term behaviour of PEI and PEI-based composites subjected to physical aging. Compos. Sci. Technol. 1999, 59, 1993-2003. [CrossRef]

248. Sergi, C.; Tirillò, J.; Seghini, M.C.; Sarasini, F.; Fiore, V.; Scalici, T. Durability of basalt/hemp hybrid thermoplastic composites. Polymers 2019, 11, 603. [CrossRef] [PubMed]

249. Wolfrum, J.; Whitney, E.; Eibl, S. Approaches to understand and predict the influence of rapid heat-up on degradation and strength of carbon fibre polymer matrix composites. J. Compos. Mater. 2017, 51, 2435-2447. [CrossRef]

250. Kim, J.; Lee, W.I. Modeling of mechanical property degradation by short-term aging at high temperatures. Key Eng. Mater. 2000, 33, 631-636. [CrossRef]

251. Carpier, Y.; Vieille, B.; Coppalle, A.; Barbe, F. About the tensile mechanical behaviour of carbon fibers fabrics reinforced thermoplastic composites under very high temperature conditions. Compos. Part B Eng. 2020, 181, 107586. [CrossRef]

252. Burcham, L.J.; Eduwee, R.F.; Gillespie, J.W. Investigation of the Microcracking Behavior of B ism alei $m$ ide Com pos i t es During Thermal Aging. Polym. Compos. 1971, 16, 507-517. [CrossRef]

253. Robert, M.; Roy, R.; Benmokrane, B. Environmental effects on glass fiber reinforced polypropylene thermoplastic composite laminate for structural applications. Polym. Compos. 2009, 16, 604-611. [CrossRef]

254. Arhant, M.; Le Gac, P.Y.; Le Gall, M.; Burtin, C.; Briançon, C.; Davies, P. Effect of sea water and humidity on the tensile and compressive properties of carbon-polyamide 6 laminates. Compos. Part A Appl. Sci. Manuf. 2016, 91, 250-261. [CrossRef]

255. Liu, H.; Wang, J.; Jiang, P.; Yan, F. Durability of fiber-reinforced polyoxymethylene composites under the high hydrostatic pressure in the deep sea. J. Appl. Polym. Sci. 2020, 137, 22-24. [CrossRef]

256. Sang, L.; Wang, Y.; Wang, C.; Peng, X.; Hou, W.; Tong, L. Moisture diffusion and damage characteristics of carbon fabric reinforced polyamide 6 laminates under hydrothermal aging. Compos. Part A Appl. Sci. Manuf. 2019, 123, 242-252. [CrossRef]

257. Davies, P.; Le Gac, P.Y.; Le Gall, M. Influence of Sea Water Aging on the Mechanical Behaviour of Acrylic Matrix Composites. Appl. Compos. Mater. 2017, 24, 97-111. [CrossRef]

258. Ma, Y.; Jin, S.; Yokozeki, T.; Ueda, M.; Yang, Y.; Elbadry, E.A.; Hamada, H.; Sugahara, T. Effect of hot water on the mechanical performance of unidirectional carbon fiber-reinforced nylon 6 composites. Compos. Sci. Technol. 2020, 200, 108426. [CrossRef]

259. Dandy, L.O.; Oliveux, G.; Wood, J.; Jenkins, M.J.; Leeke, G.A. Accelerated degradation of Polyetheretherketone (PEEK) composite materials for recycling applications. Polym. Degrad. Stab. 2015, 112, 52-62. [CrossRef]

260. Parvatareddy, H.; Wang, J.Z.; Dillard, D.A.; Ward, T.C.; Rogalski, M.E. Environmental aging of high-performance polymeric composites: Effects on durability. Compos. Sci. Technol. 1995, 53, 399-409. [CrossRef]

261. Kuruvilla, S.P.; Renukappa, N.M. Effects of nano- and micro-filler on water diffusion and leakage current of GRP composites. Lect. Notes Mech. Eng. 2019, 53-61. [CrossRef]

262. Manjunath, M.; Renukappa, N.; Suresha, B. Influence of micro and nanofillers on mechanical properties of pultruded unidirectional glass fiber reinforced epoxy composite systems. J. Compos. Mater. 2016, 50, 1109-1121. [CrossRef]

263. Roy, S.; Hussain, F.; Narasimhan, K. Characterization of mechanical properties of thermoplastic nanocomposites manufactured using pultrusion. In Proceedings of the 39th International SAMPE Technical Conference-From Art to Science: Advancing Materials and Process Engineering, Cincinnati, OH, USA, 29 October-1 November 2007. 
264. Alam, M.K.; Morosko, J.; Shin, D. Enhancement of conductivity of continuous fiber composite tapes using vapor grown nanofiber. In Proceedings of the 39th International SAMPE Technical Conference-From Art to Science: Advancing Materials and Process Engineering, Cincinnati, OH, USA, 29 October-1 November 2007.

265. Akhtar, M.N.; Sulong, A.B.; Nazir, M.S.; Majeed, K.; Radzi, M.K.F.; Ismail, N.F.; Raza, M.R. Kenaf-biocomposites: Manufacturing, characterization, and applications. Green Energy Technol. 2017. [CrossRef]

266. Lapointe, F.L.; Oswald, A.; Nakai, A.; Laberge Lebel, L. Manufacturing of carbon/polyamide beam by vacuum assisted pultrusion. In Proceedings of the ECCM 2016-Proceeding of the 17th European Conference on Composite Materials, Munich, Germany, 26-30 June 2016.

267. Yang, Y.; Murakami, M.; Hamada, H. Molding Method, Thermal and Mechanical Properties of Jute/PLA Injection Molding. J. Polym. Environ. 2012, 20. [CrossRef]

268. Nakamura, H.; Shikamoto, N.; Nakai, A.; Hamada, H. Application of continuous natural fiber reinforced biodegradable resin composites for structural member. In Proceedings of the 24th Annual Technical Conference of the American Society for Composites 2009 and 1st Joint Canadian-American Technical Conference on Composites, Newark, DE, USA, 15-17 September 2009; Volume 4.

269. Ganster, J.; Fink, H.P. Novel cellulose fibre reinforced thermoplastic materials. Cellulose 2006, 13. [CrossRef]

270. Van De Velde, K.; Kiekens, P. Biopolymers: Overview of several properties and consequences on their applications. Polym. Test. 2002, 21. [CrossRef]

271. Nunes, F.; Correia, J.R.; Silvestre, N. Structural behaviour of hybrid FRP pultruded columns. Part 1: Experimental study. Compos. Struct. 2016, 139, 291-303. [CrossRef]

272. Advani, S.G.; Sozer, M. Process Modeling in Composites Manufacturing, 2nd ed.; CRC Press: Boca Raton, FL, USA, 2010.

273. Baran, I.; Tutum, C.C.; Nielsen, M.W.; Hattel, J.H. Process induced residual stresses and distortions in pultrusion. Compos. Part B Eng. 2013, 51, 148-161. [CrossRef]

274. Baran, I.; Akkerman, R.; Hattel, J.H. Modelling the pultrusion process of an industrial L-shaped composite profile. Compos. Struct. 2014, 118, 37-48. [CrossRef]

275. Safonov, A.; Gusev, M.; Saratov, A.; Konstantinov, A.; Sergeichev, I.; Konev, S.; Gusev, S.; Akhatov, I. Modeling of cracking during pultrusion of large-size profiles. Compos. Struct. 2019, 111801. [CrossRef]

276. Hamada, H.; Maekawa, Z.-I.; Ikegawa, N.; Matsuo, T.; Yamane, M. Influence of the impregnating property on mechanical properties of commingled yarn composites. Polym. Compos. 1993, 14, 308-313. [CrossRef]

277. Ye, L.; Friedrich, K. Processing of thermoplastic composites from powder/sheath-fibre bundles. J. Mater. Process. Technol. 1995, 48, 317-324. [CrossRef]

278. Gutowski, T.G.; Morigaki, T.; Cai, Z. The Consolidation of Laminate Composites. J. Compos. Mater. 1987, 21, 172-188. [CrossRef]

279. Koubaa, S.; Burtin, C.; Lecorre, S.; Poitou, A. Simple modelling of impregnation in pultrusion process of thermoplastic composites. Int. J. Microstruct. Mater. Prop. 2012, 7, 428-438. [CrossRef]

280. Koubaa, S.; Le Corre, S.; Burtin, C. Thermoplastic pultrusion process: Modeling and optimal conditions for fibers impregnation. J. Reinf. Plast. Compos. 2013, 32, 1285-1294. [CrossRef]

281. Gibson, A.G.; Miller, A. Impregnation techniques for thermoplastic matrix composites. Polym. Polym. Compos. $1996,4,459-481$.

282. Haffner, S.M.; Friedrich, K.; Hogg, P.J.; Busfield, J.J.C. Finite Element Assisted Modelling of the Microscopic Impregnation Process in Thermoplastic Preforms. Appl. Compos. Mater. 1998, 5. [CrossRef]

283. Bechtold, G.; Kameo, K.; Langler, F.; Hamada, H.; Friedrich, K. Pultrusion of braided thermoplastic commingled yarn-simulation of the impregnation process. In Proceedings of the 5th International Conference on Flow Processes in Composite Materials, Plymouth, UK, 12-14 July 1999.

284. Koubaa, S.; Burtin, C.; Le Corre, S. Investigation of capillary impregnation for permeability prediction of fibrous reinforcements. J. Compos. Mater. 2016, 50, 1417-1429. [CrossRef]

285. Ngo, S.I.; Lim, Y.I.; Hahn, M.H.; Jung, J.; Bang, Y.H. Multi-scale computational fluid dynamics of impregnation die for thermoplastic carbon fiber prepreg production. Comput. Chem. Eng. 2017, 103. [CrossRef]

286. Lee, W.I.; Springer, G.S.; Smith, F.N. Pultrusion of thermoplastics. Int. SAMPE Symp. Exhib. 1991, 36, $1309-1318$.

287. Åstroöm, B.T.; Pipes, R.B. A Modeling Approach to Thermoplastic Pultrusion. I: Formulation of Models. Polym. Compos. 1993, 14, 173-183. [CrossRef]

288. Babeau, A.; Comas-Cardona, S.; Binetruy, C.; Orange, G. Modeling of heat transfer and unsaturated flow in woven fiber reinforcements during direct injection-pultrusion process of thermoplastic composites. Compos. Part A Appl. Sci. Manuf. 2015, 77, 310-318. [CrossRef]

289. Malkin, A.Y.; Beghishev, V.P.; Keapin, I.A. Macrokinetics of polymer crystallization. Polymer 1983, 24, 81-84. [CrossRef]

290. Haffner, S.M.; Friedrich, K.; Hogg, P.J.; Busfield, J.J.C. Finite-element-assisted modelling of a thermoplastic pultrusion process for powder-impregnated yarn. Compos. Sci. Technol. 1998, 58, 1371-1380. [CrossRef]

291. Ruan, Y.; Liu, J.G.; Chesonis, D.C.; Carvell, L.A. Development of a two-dimensional thermal model for the steady state thermoplastic pultrusion process. In Proceedings of the International SAMPE Symposium and Exhibition, Anaheim, CA, USA, 9-12 March 1992; Volume 37.

292. Carlsson, A.; Tomas Åström, B. Modeling of heat transfer and crystallization kinetics in thermoplastic composites manufacturing: Pultrusion. Polym. Compos. 1998, 19. [CrossRef] 
293. Ahmed, F.; Joshi, S.C.; Lam, Y.C. Three-dimensional FE-NCV modeling of thermoplastic composites pultrusion. J. Thermoplast. Compos. Mater. 2004, 17, 447-462. [CrossRef]

294. Joshi, S.C.; Lam, Y.C. Integrated approach for modelling cure and crystallization kinetics of different polymers in $3 \mathrm{D}$ pultrusion simulation. J. Mater. Process. Technol. 2006, 174, 178-182. [CrossRef]

295. Lee, W.I.; Springer, G.S.; Smith, F.N. Pultrusion of Thermoplastics-A Model. J. Compos. Mater. 1991, 25. [CrossRef]

296. Astrom, B.T.; Pipes, R.B. Modeling of a thermoplastic pultrusion process. Q. Soc. of Aerosp. Mater. Process Eng. $1991,22,55-64$.

297. Parasnis, N.C.; Ramani, K.; Borgaonkar, H.M. Ribbonizing of electrostatic powder spray impregnated thermoplastic tows by pultrusion. Compos. Part A Appl. Sci. Manuf. 1996, 27, 567-574. [CrossRef]

298. Blaurock, J.; Michaeli, W. Calculation of the pulling force in the thermoplastics pultrusion process. In Proceedings of the International SAMPE Symposium and Exhibition (Proceedings), Anaheim, CA, USA, 4-8 May 1997; Volume 42.

299. Baran, I.; Tutum, C.C.; Hattel, J.H.; Akkerman, R. Pultrusion of a vertical axis wind turbine blade part-I: 3D thermo-chemical process simulation. Int. J. Mater. Form. 2015, 8, 379-389. [CrossRef]

300. Baran, I.; Hattel, J.H.; Tutum, C.C.; Akkerman, R. Pultrusion of a vertical axis wind turbine blade part-II: Combining the manufacturing process simulation with a subsequent loading scenario. Int. J. Mater. Form. 2015, 8, 367-378. [CrossRef]

301. Struzziero, G.; Teuwen, J.J.E.; Skordos, A.A. Numerical optimisation of thermoset composites manufacturing processes: A review. Compos. Part A Appl. Sci. Manuf. 2019, 124. [CrossRef]

302. Coelho, R.M.L.; Calado, V.M.A. An optimization procedure for the pultrusion process based on a finite element formulation Polym. Compos. 2002, 23, 329-341. [CrossRef]

303. Santos, L.S.; Pagano, R.L.; Biscaia, E.C.; Calado, V.M.A. Optimum heating configuration of pultrusion process. Comput. Aided Chem. Eng. 2009, 27, 705-710. [CrossRef]

304. Santos, L.S.; Pagano, R.L.; Calado, V.M.A.; Biscaia, E.C.J. Optimization of a pultrusion process using finite difference and particle swarm algorithms. Brazilian J. Chem. Eng. 2015, 32, 543-553. [CrossRef]

305. Acquah, C.; Datskov, I.; Mawardi, A.; Zhang, F.; Achenie, L.E.K.; Pitchumani, R.; Santos, E. Optimization under uncertainty of a composite fabrication process using a deterministic one-stage approach. Comput. Chem. Eng. 2006, 30, 947-960. [CrossRef]

306. Mawardi, A.; Pitchumani, R. Cure cycle design for thermosetting-matrix composites fabrication under uncertainty. Ann. Oper. Res. 2004, 132, 19-45. [CrossRef]

307. Li, J.; Joshi, S.C.; Lam, Y.C. Curing optimization for pultruded composite sections. Compos. Sci. Technol. 2002, 62, 457-467. [CrossRef]

308. Lam, Y.C.; Li, J.; Joshi, S.C. Simultaneous Optimization of Die-Heating and Pull-Speed in Pultrusion of Thermosetting Composites. Polym. Compos. 2003, 24, 199-209.

309. Joshi, S.C.; Lam, Y.C.; Win Tun, U. Improved cure optimization in pultrusion with pre-heating and die-cooler temperature. Compos. Part A Appl. Sci. Manuf. 2003, 34, 1151-1159. [CrossRef]

310. Carlone, P.; Palazzo, G.S.; Pasquino, R. Pultrusion manufacturing process development: Cure optimization by hybrid computational methods. Comput. Math. Appl. 2007, 53, 1464-1471. [CrossRef]

311. Costa Dias, R.D.C.; Santos, L.D.S.; Ouzia, H.; Schledjewski, R. Improving degree of cure in pultrusion process by optimizing die-temperature. Mater. Today Commun. 2018, 17, 362-370. [CrossRef]

312. Chen, X.; Jiang, B.; Zhou, Z. Optimization of CFRP pultrusion process with NSGA-II and ANN. Adv. Mater. Res. 2012, 538-541, 2705-2711. [CrossRef]

313. Chen, X.; Xie, H.; Chen, H.; Zhang, F. Optimization for CFRP pultrusion process based on genetic algorithm-neural network. Int. J. Mater. Form. 2010, 3, 1391-1399. [CrossRef]

314. Baran, I.; Tutum, C.C.; Hattel, J.H. Optimization of the thermosetting pultrusion process by using hybrid and mixed integer genetic algorithms. Appl. Compos. Mater. 2013, 20,449-463. [CrossRef]

315. Tutum, C.C.; Baran, I.; Hattel, J.H. Utilizing multiple objectives for the optimization of the pultrusion process based on a thermo-chemical simulation. Key Eng. Mater. 2013, 554-557, 2165-2174. [CrossRef]

316. Tutum, C.C.; Baran, I.; Deb, K. Optimum design of pultrusion process via evolutionary multi-objective optimization. Int. J. Adv. Manuf. Technol. 2014, 72, 1205-1217. [CrossRef]

317. Safonov, A.; Bondarchuk, D.; Saratov, A.; Ushakov, A.; Akhatov, I. Optimal process design for large-scale pultrusion structures. In Proceedings of the ICCM International Conferences on Composite Materials; International Committee on Composite Materials, Xi'an, China, 20-25 August 2017; Volume 2017.

318. Safonov, A.A. 3D topology optimization of continuous fiber-reinforced structures via natural evolution method. Compos. Struct. 2019, 215, 289-297. [CrossRef]

319. The European Pultrusion Technology Association: EPTA. Available online: https://pultruders.org (accessed on 21 December 2020).

320. Global Thermoplastic Composites Market Report. Available online: https://www.researchandmarkets.com/reports/5136171/thermoplastic-composites-market-by-resin-type (accessed on 4 January 2021).

321. Witten, E.; Mathes, V. The Market for Glass Fibre Reinforced Plastics (GRP) in 2020. Market Developments, Trends, Outlooks and Challenges; Federation of Reinforced Plastics: Frankfurt, Germany, 2020.

322. Nelson, S.M.; Eastep, D.W.; Regan, T.A.; Wesley, M.L.; Stiehm, R. Structural Member Formed from a Solid Lineal Profile. U.S. Patent 9238347B2, 11 June 2016. 
323. Zhang, Y.; Zhang, R.; Jing, R.; Wang, Y.; Meng, Y.; Zhao, Y.; Wei, K.; Zhang, X. Production Device for Thermoplastic Composite Yarn Pultrusion Plates. C.N. Patent 209999713U, 27 February 2020.

324. Bordellier, F.; Callens, C.; Masson, C.; Broek, G. Van Den Installation and Method for Pultrusion of Banded Composite Material. F.R. Patent 3068286A1, 30 June 2017.

325. Zhu, Z.; Yang, C.; Luo, G.; Liu, F. Novel Wiper Elastic Sheet and Preparation Method Thereof. C.N. Patent 110654041A, 30 September 2020.

326. Nelson, S.M.; Eastep, D.W.; Tibor, T.L.; Regan, T.A.; Wesley, M.L.; Stiehm, R. Continuous Fiber Reinforced Thermoplastic Rod and Pultrusion Method for Its Manufacture. U.S. Patent 20140106166A1, 12 March 2020.

327. Nelson, S.M.; Eastep, D.W.; Tibor, T.L.; Regan, T.A.; Wesley, M.L. Continuous Fiber Reinforced Thermoplastic Rod and Pultrusion Method for Its Manufacture. U.S. Patent 10676845B2, 12 March 2011.

328. Cui, C.; Wu, Y. Preparation Device for Fiber Reinforced Composite Material Anti-Eccentric Wearing Continuous Sucker rod. C.N. Patent 202965218U, 30 November 2012.

329. Szaplonczay, P. Method and Instalation for Fabrication of Heat Resistant Transmission Line Having a Thermo Softening Core. H.U. Patent 228364B1, 24 March 2008.

330. Zhu, B.; Cai, X.; Wang, C.; Cai, H. Composite Wire Core Bar with Thermoplastic Resin Substrate and Preparation Die and Process Thereof. C.N. Patent 102024518B, 1 November 2010.

331. Yao, J.; Wei, J.; Xu, J.; Chen, T.; Zheng, Z.; Yu, H. A kind of Pulltrusion Device for Producing Thermoplastic Matrix Layer. C.N Patent 206765399U, 17 March 2017.

332. Hirotoshi, I.; Hirotoshi, I.; Takuya, T.; Takuya, T. Thin-Walled Tube Manufacturing Method, Tube Manufactured by the Manufacturing Method, and Multilayer Structure Tube. J.P. Patent 5655020B2, 28 February 2015.

333. Liu, B.; Liu, B. A Kind of Fiberglass Pultrusion, the Preparation Process of the Duplexing Skill Compound Bellows of Winding. C.N. Patent 108006334A, 12 December 2017.

334. Nelson, S.M.; Eastep, D.W.; Regan, T.A. Reinforced Hollow Profiles. E.P. Patent 2585278A2, 22 June 2010.

335. Gusev, S.; Safonov, A.; Rubtsov, M.; Sergeichev, I.; Akhatov, I. Thermoplastic Reinforced Pultrusion Profile. R.U. Patent 2738606C1, 8 April 2020.

336. Schmidt, S.; Fink, N.; Rhönisch, T.; Al-Sheyyab, A. Process for Producing a Thermoplastic Window or Door Hollow Chamber Profile. D.E. Patent 102016119766A1, 18 October 2016.

337. Safonov, A.; Gusev, S.; Rubtsov, M.; Sergeichev, I.; Akhatov, I. Thermoplastic Pultrusion Reinforcement Insert in a Hollow Plastic Frame of a Window or Door Unit. R.U. Patent 2738062C1, 31 July 2020.

338. Preisler, D.J.; Peash, D.A. Reinforced Composite Pallet Assembly of the Cellular Core Sandwich-Type. U.S. Patent 6655299B2, 30 October 2003.

339. Preisler, D.J. Reinforced Composite Vehicle Load Floor of the Cellular Core Sandwich-Type. U.S. Patent 6843525B2, 30 October 2001.

340. Gao, K.; Li, G.; Zhou, G.; Ma, S. A Kind of Composite Material Truck Fuel Tanks Bracket with Skeleton Enhancing. C.N. Patent 109050240A, 24 July 2018.

341. Edward O'Connor, J.; Rocco Bonazza, B.; Thomas Webster, J. Method for Producing Reinforced Thermoplastic Composite-Metallic Foil Laminated Articles. E.P. Patent 0372505A2, 7 December 1989.

342. Zhu, B.; Cao, W.; Wang, Y.; Qiao, K.; Zhang, M. A Kind of Pultrusion Composite Board. C.N. Patent $209700001 U, 20$ July 2018.

343. Nelson, S.M.; Eastep, D.W.; Regan, T.A. Method for Forming Reinfoced Pultruded Profiles. U.S. Patent 20130149521A1, 22 June 2010.

344. Guan, Y.; Qu, X.; Shi, Y.; Qu, C. Direct On-Line Pultrusion Process for Fiber Reinforced Thermoplastic Composite material. C.N. Patent 102336026B, 25 November 2011.

345. Kang, K.; Wang, P.; Lei, Y. A Kind of Continuously Shaped Matrix Device of Intelligence Composite Material Thermoplastic and Method. C.N. Patent 109648891A, 14 December 2018.

346. Nelson, S.M.; Eastep, D.W.; Regan, T.A. Method for Forming Reinforced Pultruded Profiles. U.S. Patent 9409347B2, 22 June 2011.

347. Dufresne, R.P. Insulating Anti-Corrosive Rail Clamp Integrally Made of Polymeric Composition. U.S. Patent 20100044451A1, 5 January 2014.

348. Chauzu, F. Process for Obtaining a Thermoplastic Composite Composite Curved Piece and Installation for Implementing said Method. F.R. Patent 3053912B1, 18 July 2016.

349. Balazek, D.T.; Griffiths, T.J.; Pearson, D.E. Pultrusion/Extrusion Method. U.S. Patent 4938823A, 7 October 1988.

350. Schmidt, S.; Pardos, S.; Goldstein, J.; Al-Sheyyab, A. Process for Producing a Thermoplastic Extruded Profile. D.E. Patent 102016119765A1, 18 October 2016.

351. Offringa, A.R. Thermoplastic composites-Rapid processing applications. Compos. Part A Appl. Sci. Manuf. 1996, 27, 329-336. [CrossRef]

352. Plastic Bumper Beam Produced by Curved Reactive Thermoplastic Pultrusion (CRTP). Available online: https://www.plastics.gl/ automotive/plastic-bumper-beam-produced-by-curved-reactive-thermoplastic-pultrusion-crtp-2/ (accessed on 21 December 2020).

353. David, K. Method for Manufacturing a Wheel Rim from Fibre Composite Material and Wheel Rim for a Motor Vehicle. European Patent EP2626218A1, 14 August 2013. 
354. Balaji Thattaiparthasarathy, K.; Pillay, S.; Ning, H.; Vaidya, U.K. Process simulation, design and manufacturing of a long fiber thermoplastic composite for mass transit application. Compos. Part A Appl. Sci. Manuf. 2008, 39, 1512-1521. [CrossRef]

355. Brøndsted, P.; Lilholt, H.; Lystrup, A. Composite materials for wind power turbine blades. Annu. Rev. Mater. Res. 2005, 35, 505-538. [CrossRef]

356. Davies, P.; Riou, L.; Mazeas, F.; Warnier, P. Thermoplastic composite cylinders for underwater applications. J. Thermoplast. Compos. Mater. 2005, 18, 417-443. [CrossRef]

357. Shayan Asenjan, M.; Sabet, S.A.R.; Nekoomanesh, M. Mechanical and high velocity impact performance of a hybrid long carbon/glass fiber/polypropylene thermoplastic composite. Iran. Polym. J. 2020, 29, 301-307. [CrossRef]

358. Kim, Y.; Park, O.O. Effect of Fiber Length on Mechanical Properties of Injection Molded Long-Fiber-Reinforced Thermoplastics. Macromol. Res. 2020, 28, 433-444. [CrossRef]

359. Barkoula, N.M.; Garkhail, S.K.; Peijs, T. Effect of compounding and injection molding on the mechanical properties of flax fiber polypropylene composites. J. Reinf. Plast. Compos. 2010, 29, 1366-1385. [CrossRef]

360. Fujiura, T.; Okamoto, T.; Tanaka, T.; Imaida, Y. Improvement of mechanical properties of long jute fiber reinforced polylactide prepared by injection molding process. WIT Trans. Ecol. Environ. 2010, 138, 181-188. [CrossRef]

361. Fujiura, T.; Sakamoto, K.; Tanaka, T.; Imaida, Y. A study on preparation and mechanical properties of long jute fiber reinforced polylactic acid by the injection molding process. In Proceedings of the WIT Transactions on the Built Environment, Algarve, Portugal, 13-15 May 2008; Volume 97, pp. 231-240.

362. Takai, Y.; Kawai, N.; Nakai, A.; Hamada, H. Fabrication of long fiber reinforced thermoplastic composites with pultrusion technique. In Proceedings of the American Society for Composites-21st Technical Conference of the American Society for Composites, Dearborn, MI, USA, 17-20 September 2006; Volume 3, pp. 1649-1656.

363. Truckenmüller, F.; Fritz, H.-G. Injection molding of long fiber-reinforced thermoplastics: A comparison of extruded and pultruded materials with direct addition of roving strands. Polym. Eng. Sci. 1991, 31, 1316-1329. [CrossRef]

364. Fernandes, E.M.; Correlo, V.M.; Chagas, J.A.M.; Mano, J.F.; Reis, R.L. Properties of new cork-polymer composites: Advantages and drawbacks as compared with commercially available fibreboard materials. Compos. Struct. 2011, 93, 3120-3129. [CrossRef]

365. Fernandes, E.M.; Correlo, V.M.; Chagas, J.A.M.; Mano, J.F.; Reis, R.L. Cork based composites using polyolefin's as matrix: Morphology and mechanical performance. Compos. Sci. Technol. 2010, 70, 2310-2318. [CrossRef]

366. Wolf, H.J. Screw plasticating of discontinuous fiber filled thermoplastic: Mechanisms and prevention of fiber attrition. Polym. Compos. 1994, 15, 375-383. [CrossRef]

367. Kadowaki, R.; Hirano, Y.; Asai, T. Fiber-Reinforced Thermoplastic Resin Pellets and Manufactuing Method Thereof. U.S. Patent 6,620,507, 16 October 2003.

368. Hennige, K. Industry 4.0 materials handling components and innovative LFT pellets. JEC Compos. Mag. 2017, 54, 35-36.

369. Ascione, L.; Caron, J.-F.; Godonou, P.; van Ijselmuijden, K.; Knippers, J.; Mottram, J.; Oppe, M.; Gantriis Sorensen, M.; Taby, J.; Tromp, L. Prospect for New Guidance in the Design of FRP. Support to the Implementation, Harmonization and Further Development of the Eurocodes; Publication Office of the EU: Rue Mercier, Luxembourg, 2016.

370. Grimaldi, A. Guide for the Design and Construction of Structures made of FRP Pultruded Elements. CNR-Dt 2007, $205,25-31$.

371. Clarke, J.L. Structural Design of Polymer Composites: EUROCOMP Design Code and Handbook; CRC Press: Boca Raton, FL, USA, 1996; ISBN 9780419194507.

372. American Society for Civil Engineers. Pre-Standard for Load and Resistance Factor Design (LRFD) of Pultruded Fiber Reinforced Polymer (FRP) Structures (Final). Am. Compos. Manuf. Assoc. 2010. Available online: Http://Dev1.Israelfanatic.com/ information/specifications/specs-resources/LRFD\%20prestandard\%20-\%20revised\%20final\%20-20Nov\%209\%202010.PDF\% 20Nov\%209\%202010.PDF (accessed on 21 December 2020).

373. Asyraf, M.R.M.; Ishak, M.R.; Sapuan, S.M.; Yidris, N.; Ilyas, R.A.; Rafidah, M.; Razman, M.R. Potential application of green composites for cross arm component in transmission tower: A brief review. Int. J. Polym. Sci. 2020, 2020. [CrossRef]

374. Meng, F.; Olivetti, E.; Zhao, Y.; Chang, J.C.; Pickering, S.J.; Mckechnie, J.; Accepted, J. Fibre Composite Recycling Technologies and Waste Management Options Comparing Life Cycle Energy and Global Warming Potential of Carbon Fibre Composite Recycling Technologies and Waste Management Options. ACS Sustain. Chem. Eng. 2018. [CrossRef]

375. Zhang, J.; Chevali, V.S.; Wang, H.; Wang, C. Current status of carbon fibre and carbon fibre composites recycling. Compos. Part B 2020, 193, 108053. [CrossRef]

376. Stavrov, D.; Bersee, H.E.N. Resistance welding of thermoplastic composites-an overview. Compos. Part A Appl. Sci. Manuf. 2005, 36, 39-54. [CrossRef]

377. Bhudolia, S.K.; Gohel, G.; Leong, K.F.; Islam, A. Advances in ultrasonicwelding of thermoplastic composites: A review. Materials 2020, 13, 1284. [CrossRef] [PubMed]

378. da Costa, A.P.; Botelho, E.C.; Costa, M.L.; Narita, N.E.; Tarpani, J.R. A review of welding technologies for thermoplastic composites in aerospace applications. J. Aerosp. Technol. Manag. 2012, 4, 255-265. [CrossRef]

379. Amanat, N.; James, N.L.; McKenzie, D.R. Welding methods for joining thermoplastic polymers for the hermetic enclosure of medical devices. Med. Eng. Phys. 2010, 32, 690-699. [CrossRef]

380. Tanimoto, Y.; Inami, T.; Yamaguchi, M.; Kasai, K.; Hirayama, N.; Aoki, Y. Characterization of Esthetic Orthodontic Wires Made from Glass-Fiber-Reinforced Thermoplastic Containing High-Strength, Small-Diameter Glass Fibers. Adv. Mater. Sci. Eng. 2018, 2018. [CrossRef] 
381. Tanimoto, Y.; Inami, T.; Yamaguchi, M.; Nishiyama, N.; Kasai, K. Preparation, mechanical, and in vitro properties of glass fiber-reinforced polycarbonate composites for orthodontic application. J. Biomed. Mater. Res. Part B Appl. Biomater. 2015, 103, 743-750. [CrossRef]

382. Brack, A.; Janssen, H.; Brecher, C. Manufacturing of miniaturized thermoplastic frp components using a novel reaction injection pultrusion process. In Proceedings of the International SAMPE Technical Conference; Soc. for the Advancement of Material and Process Engineering, Seattle, CA, USA, 22-25 May 2017; pp. 944-957.

383. Brecher, C.; Emonts, M.; Brack, A.; Schotte, A. Micro-puliwinding and micro-pultrusion-Technology and applications. JEC Compos. Mag. 2012, 49, 71-73.

384. Krueger, S.; Schmitz, S.; Weiss, S.; Wirtz, D.; Linssen, M.; Schade, H.; Kraemer, N.; Spuentrup, E.; Krombach, G.; Buecker, A. An MR guidewire based on micropultruded fiber-reinforced material. Magn. Reson. Med. 2008, 60, 1190-1196. [CrossRef]

385. Krämer, N.A.; Krüger, S.; Schmitz, S.; Linssen, M.; Schade, H.; Weiss, S.; Spüntrup, E.; Günther, R.W.; Bücker, A.; Krombach, G.A. Preclinical evaluation of a novel fiber compound MR guidewire in vivo. Investig. Radiol. 2009, 44, 390-397. [CrossRef]

386. Callens, S.J.P.; Bergsma, O.K. Two-matrix composites: Carbon fiber micropultrusions embedded in flexible epoxy matrices. Compos. Part A Appl. Sci. Manuf. 2018, 114, 1-12. [CrossRef]

387. Eichenhofer, M.; Wong, J.C.H.; Ermanni, P. Continuous lattice fabrication of ultra-lightweight composite structures. Addit. Manuf. 2017, 18. [CrossRef]

388. Eichenhofer, M.; Wong, J.C.H.; Ermanni, P. Exploiting cyclic softening in continuous lattice fabrication for the additive manufacturing of high performance fibre-reinforced thermoplastic composite materials. Compos. Sci. Technol. 2018, 164. [CrossRef]

389. Eichenhofer, M.; Wong, J.C.H.; Ermanni, P. Experimental investigation of processing parameters on porosity in continuous lattice fabrication. In Proceedings of the ICCM International Conferences on Composite Materials, Xi'an, China, 20-25 August 2017; Volume 2017.

390. Hopmann, C.; Schneider, P.; Boettcher, A. Manufacturing of hybrid profiles: Continuous fiber reinforced thermoset profiles with a thermoplastic top layer. In Proceedings of the SAMPE Journal, Long Beach, CA, USA, 23-26 May 2016; Volume 52.

391. Wilson, M.L.; MacConochie, I.O.; Johnson, G.S. Potential for on-Orbit Manufacture of Large Space Structures Using the Pultrusion Process; NASA Technical Memorandum: Hampton, VA, USA, 1 January 1987.

392. Wilson, M.L.; MacConachie, I.O.; Johnson, G.S. Space structures. Built in space. Mod. Plast. 1988, 65, 102-108.

393. Wilson, M.L.; MacConochie, I.O.; Johnson, G.S. On-orbit fabrication of large space structures using thermoplastic preimpregnated graphite tapes and a pultrusion process. In Proceedings of the Society of the Plastics Industry, Reinforced Plastics/Composites Institute, Annual Conference-Proceedings, Cincinnati, OH, USA, 1-5 February 1988.

394. UK Company Plans to Boldly Go and Make Machines in Space. Available online: https://www.ft.com/content/951acff2-b20e-11 e4-80af-00144feab7de (accessed on 21 December 2020).

395. Liu, T.; Feng, P.; Wu, Y.; Liao, S.; Meng, X. Developing an innovative curved-pultruded large-scale GFRP arch beam. Compos. Struct. 2021, 256. [CrossRef]

396. Tonatto, M.L.P.; Tita, V.; Amico, S.C. Composite spirals and rings under flexural loading: Experimental and numerical analysis. J. Compos. Mater. 2020. [CrossRef]

397. Curved Pultrusion? No Longer an Oxymoron. Available online: https://www.compositesworld.com/articles/curved-pultrusionno-longer-an-oxymoron (accessed on 18 December 2020).

398. Ringenbach, S.; Richeton, J.; Coulton, J. Hyundai's breakthrough front bumper crash beam. JEC Compos. Mag. $2015,98,39-41$.

399. An Expanded Role for Pultruded Composites in 5G Cities. Available online: https://pultruders.org/news-details.php?id=31 (accessed on 21 December 2020).

400. Aguilar, M.R.; San Román, J. Introduction to Smart Polymers and Their Applications; Woodhead Publishing: Sawston, UK; Cambridge, UK, 2014; ISBN 9780857096951.

401. Sun, L.; Huang, W.M.; Ding, Z.; Zhao, Y.; Wang, C.C.; Purnawali, H.; Tang, C. Stimulus-responsive shape memory materials: A review. Mater. Des. 2012, 33, 577-640. [CrossRef]

402. Xin, X.; Liu, L.; Liu, Y.; Leng, J. Mechanical Models, Structures, and Applications of Shape-Memory Polymers and Their Composites. Acta Mech. Solida Sin. 2019, 32, 535-565. [CrossRef]

403. Meng, H.; Li, G. A review of stimuli-responsive shape memory polymer composites. Polymer 2013, 54, 2199-2221. [CrossRef]

404. Pilate, F.; Toncheva, A.; Dubois, P.; Raquez, J.-M. Shape-memory polymers for multiple applications in the materials world. Eur. Polym. J. 2016, 80, 268-294. [CrossRef]

405. Liu, Y.; Du, H.; Liu, L.; Leng, J. Shape memory polymers and their composites in aerospace applications: A review. Smart Mater. Struct. 2014, 23. [CrossRef]

406. Xie, F.; Huang, L.; Leng, J.; Liu, Y. Thermoset shape memory polymers and their composites. J. Intell. Mater. Syst. Struct. 2016, 27, 2433-2455. [CrossRef] 